\title{
The Engineering Geological Characterisation of the Barzaman Formation, with reference to Coastal Dubai, UAE
}

\author{
Steve Macklin \\ Associate Director, Arup Geotechnics, London \\ e-mail: steve.macklin@arup.com \\ Richard Ellison \\ Regional Manager, British Geological Survey \\ Jason Manning \\ Senior Geologist, Arup Geotechnics, London \\ Andrew Farrant \\ Geologist, British Geological Survey \\ Leon Lorenti \\ Senior Geotechnical Engineer, Arup Pty Ltd, Perth
}

\begin{abstract}
This paper describes, from field exposures, temporary excavations and borehole core, the pedogenically altered fluvial deposits found in the UAE termed the Barzaman Formation. This formation comprises a sequence of rocks dominated by variably cemented conglomerates thought to be middle Miocene to Pliocene in age. The sequence is interpreted as an alluvial fan succession (or "bajada") laid down in response to uplift and erosion of the Hajar Mountains. A ground model for this formation is described to explain the distinct lithological features of the formation, comprising terrestrial fluvial and alluvial plain deposits that have been modified by cementation and dolomitisation, duricrust formation and pedogenic processes during arid periods over repeated climatic cycles. Four principle lithologies thus typically occur as a rhythmic alternation of a basal conglomerate (composed predominantly of clasts of ophiolite and chert) overlain by an irregular bed of white conglomerate and "calcisiltite" and passing upwards into a pale grey to green clay and siltstone "breccia". The white conglomerate and calcisiltite largely represent deposits of dolomite-palygorskite duricrust. The well established Clarke \& Walker (1979) descriptive scheme currently used for describing the formation is reviewed and a simple visual descriptive lithological classification proposed. The classification is described in terms of the three principal lithological components visible in hand specimen: mottled white calcisiltite matrix/cement, palygorskite rich marl and clasts derived from the Oman Mountains (gabbro, chert and weathered ultramafic rock). Data on the mineralogy and microstructure of the rock constituents is also presented and some implications for geotechnical characterisation of the formation briefly discussed.
\end{abstract}

Key words: Barzaman Formation; Dubai; engineering geology; stratigraphy; mineralogy; index properties. 


\section{Introduction}

Dubai, on the southern coast of The Gulf (Figure 1) has undergone a substantial increase in development since the 1990's, mainly comprising hotel, mixed use business and residential development and infrastructure. High profile projects include the "Burj Khalifa" (formerly "Burj Dubai") tower in the Business Bay district (Baker et al, 2007), the Mall of the Emirates (Alrifai, 2007), the Dubai Waterfront (canals and residential developments), the Dubai Metro and the proposed Arabian Canal - a 75km long inland canal around which residential and light industrial development to house up to 3 million people is planned.

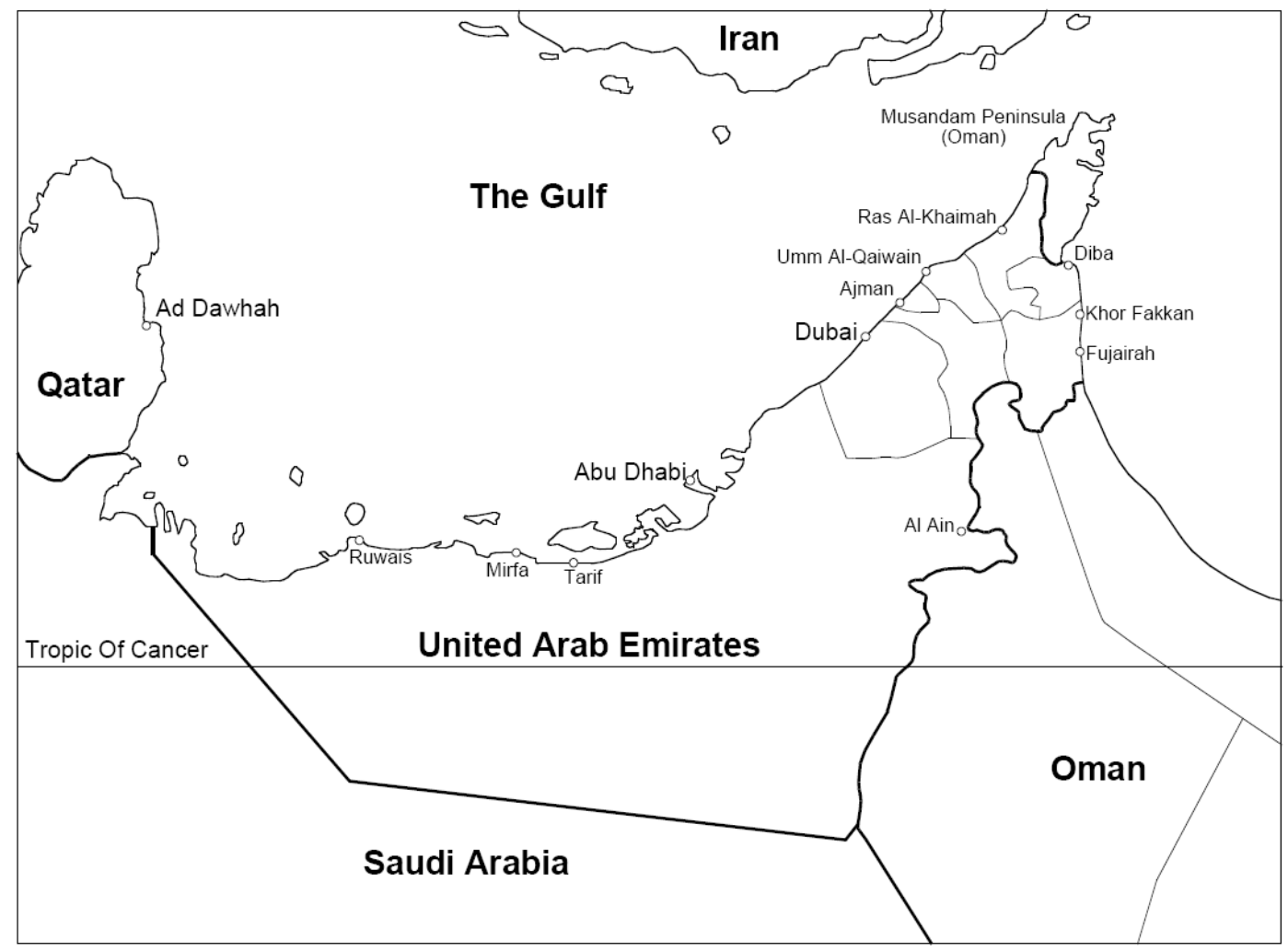

Fig. 1 Outline UAE political map

The near surface geology of coastal Dubai consists of Quaternary marine, aeolian, sabkha and fluvial deposits overlying variably cemented Pleistocene sands (aeolianite and marine calcarenite), in turn overlying the Barzaman Formation, which comprises a thick succession of fluvial sediments characterised by poorly sorted conglomerates. These conglomerates are dominated by clasts of harzburgite, chert and limestone, set within a dolomitic cement; although the degree of cementation is variable and local palaeosol horizons can also be recognised. Although largely obscured by dune fields, the Barzaman Formation can be traced in boreholes and sporadic exposures from the coast to the mountain front $60 \mathrm{~km}$ or more to the east.

The 1:250,000 geological map of Dubai (UAE Government, 1979) shows the geology exposed in coastal Dubai to comprise Quaternary aeolian, sabkha and 
gravel lag sediments and "miliolite" (calcarenite). Occasional inliers of Tertiary ${ }^{1}$ rocks are described as an evaporite sequence, comprising: “...rubbly dolomitic limestone overlain by red sandstone...sandstones, sandy limestones, marl, with gypsum and mudstone interbeds and minor conglomerates...". It is inferred that the "rubbly dolomitic limestone" and "conglomerates" represent limited coastal outcrop of the Barzaman Formation.

Outcrops of these rocks are shown to the south of the E77 Lahbab Road west of Tawi Murrah; to the east of the E77 Lahbab Road near Al Lisaili; and, just to the east of the E66 near Umm Nahad airport. Another outcrop is shown at the Jebal Ali Satellite Station near the junction of the Sheikh Zayed Road and E11 Lahbab road, however some of this outcrop may in fact represent deeper mudstones of the Fars Group brought up to the near surface by salt diapirism. Recent excavations for the proposed Arabian Canal also indicate that the Barzaman Formation subcrops in interdune areas in southern Dubai. Another possible outcrop, just to the east of the Dubai Creek on the E44 appears to have been lost to recent development.

Nonetheless, relatively widespread outcrops can be found close to the mountain front west of Dhaid (Adh Dhed) where they are interpreted as proximal alluvial fan deposits (Styles et al, 2006). These outcrops have in turn been correlated with the Barzaman Formation of Miocene to Pliocene age, as defined further south along the mountain front in Oman (e.g. Maizels, 1988).

In many coastal boreholes and excavations in Dubai thin beds of polymictic conglomerate have been noted within the Pleistocene sandstones, occasionally separating the red-brown aeolianite from the light coloured calcarenite. Open excavations and boreholes seen further inland suggest that the aeolianite/calcarenite diminish in thickness and conglomerates and pale brown sandstone may directly overlie the Barzaman Formation. Similarly Maizels (1988) and Abrams \& Chadwick (1994) mapped Pleistocene wadi gravel deposits overlying the Barzaman Formation type rocks. It is thus considered that conglomerates and sandstones of Pleistocene age may be intercalated with the Pleistocene calcarenite/aeolianite overlying the Barzaman Formation in the coastal areas of Dubai.

The lower contact of the Barzaman Formation is not at present clearly defined in the coastal areas. However deeper boreholes typically encounter an inter-bedded sequence of laminated and thinly bedded marls, fine-grained carbonate rocks and conglomerates above a gypsum-carbonate mudstone sequence thought to be equivalent to the Fars Group. A tentative stratigraphic scheme summarising a simplified geological sequence for coastal Dubai is presented in Table 1.

Recent excavations in the coastal area of Dubai have exposed good sections in the Barzaman Formation which for the first time have enabled detailed geotechnical descriptions to be made and, more importantly, interpretation of the succession in the light of the Styles et al (2006) mapping of outcrops close to the mountain front. In the course of this work it became apparent that there has hitherto been a degree of inconsistency in the descriptions provided in routine investigation reports in the Dubai area. As the Barzaman Formation is the principal load-bearing stratum beneath many of the new developments in the

\footnotetext{
${ }^{1}$ The term for the Tertiary Period in the geological time scale has now been subdivided and the terminology superseded by the Palaeogene and Neogene Periods - International Commission on Stratigraphy (2008) - www.stratigraphy.org (Ogg et al, 2008).
} 
Dubai area, its lithology and in particular its variability is of relevance for the design of piled structures and deep excavations for basements and tunnels.

\begin{tabular}{|c|c|c|}
\hline & Stratum name and age & Typical lithogical description, features \\
\hline $\begin{array}{l}\text { Up to } \\
20 \mathrm{~m} \\
\text { thick }\end{array}$ & $\begin{array}{l}\text { Holocene } \\
\text { sands and silts }\end{array}$ & $\begin{array}{l}\text { Aeolian, marine, intertidal and sabkha } \\
\text { sediments associated with the Holocene sea } \\
\text { level maximum. }\end{array}$ \\
\hline $\begin{array}{l}\text { Up to } \\
25 \mathrm{~m} \\
\text { thick }\end{array}$ & $\begin{array}{l}\text { Pleistocene "white" } \\
\text { calcarenite } \\
\text { Ghayathi Fm }\end{array}$ & $\begin{array}{l}\text { Off white to grey homogeneous to cross } \\
\text { bedded (occasionally shelly and oolitic) weak } \\
\text { calcium carbonate rich sandstone - often seen } \\
\text { in relict "zeugen" }{ }^{2} \text { outcrop, with a distinct cross } \\
\text { bedding } \\
\text { (interbedded with/or replaced by conglomerate } \\
\text { and/or sandstone in places) }\end{array}$ \\
\hline $\begin{array}{l}\text { Up to } \\
7 \mathrm{~m} \\
\text { thick }\end{array}$ & $\begin{array}{l}\text { Pleistocene red } \\
\text { sandstone and } \\
\text { conglomerate } \\
\text { (?Ghayathi Fm) }\end{array}$ & $\begin{array}{l}\text { Red-brown, occasional cross bedded, } \\
\text { gypsiferous quartz sandstone/aeolianite; } \\
\text { (interbedded with/or replaced by conglomerate } \\
\text { and/or sandstone in places) }\end{array}$ \\
\hline $\begin{array}{l}\text { Up to } \\
60 \mathrm{~m} \\
\text { thick }\end{array}$ & $\begin{array}{l}\text { Mio-Pliocene } \\
\text { Barzaman Fm }\end{array}$ & $\begin{array}{l}\text { Cemented and pedogenically altered wadi } \\
\text { conglomerates comprising: } \\
\text { - } \quad \text { Polymictic clast-supported brown } \\
\text { conglomerate (palaeo-wadi gravels) } \\
\text { - } \quad \text { Matrix supported polymictic white } \\
\text { conglomerate (duricrust formed on } \\
\text { gravels) } \\
\text { - White carbonate siltstone/marl (few } \\
\text { or no visible clasts) mostly composed } \\
\text { of a dolomite-palygorskite rich rock } \\
\text { Breccia - comprising clasts (mainly of } \\
\text { the carbonate siltstone) within a } \\
\text { palygorskite-dolomite matrix } \\
\text { Rare "gravelly sandstone" also occur, probably } \\
\text { representing relict "inter-fluve" sediments } \\
\text { between wadi channels }\end{array}$ \\
\hline $\begin{array}{l}\text { Up to } \\
25 \mathrm{~m} \\
\text { thick }\end{array}$ & $\begin{array}{l}\text { Miocene thinly bedded } \\
\text { to laminated marls and } \\
\text { limestones } \\
\text { Fars Group }\end{array}$ & $\begin{array}{l}\text { Thinly bedded/laminated to thick bedded } \\
\text { white, red-brown and greenish grey carbonate } \\
\text { siltstone and marl, with thin inter-beds of } \\
\text { polymictic conglomerate }\end{array}$ \\
\hline
\end{tabular}

Table 1 Tentative stratigraphic scheme for coastal Dubai

This paper describes a geological model for the Barzaman Formation and proposes a simplified descriptive scheme for engineering purposes, developed in the light of that model. It is considered that by adopting a more consistent

\footnotetext{
${ }^{2}$ zeuge translates from German to English as "witness", zeugen as "testify" - meaning that these features, formed mainly by aeolian erosion (deflation), remain as evidence of past geological and climatic processes.
} 
approach to lithological classification in future investigations, designers will be able to obtain a better understanding of the variability of the geotechnical characteristics of the formation. New data on the mineralogy and microstructure of the Barzaman Formation with implications for sampling and testing in routine geotechnical investigations is also discussed.

\section{Regional geological and geomorphological setting}

The Neogene rocks of the eastern Arabian Peninsula and the Rub-Al-Khali, from Kuwait to the north and Dubai to the east, comprise a substantial thickness of carbonate, clastic and evaporite sedimentary rocks, deposited in relatively stable conditions on the "Arabian Shield" over an extended period of geological time.

The strata were laid down in a variety of environments of deposition, principally shallow marine, intertidal, sabkha and fluvial environments such as are currently active in the Gulf today (Alsharhan \& Kendall, 2003).

These rocks have also been affected by relatively gentle deformations associated with the ongoing anti-clockwise movement of the Arabian plate towards the Eurasian plate. Resulting strata dips in the UAE are generally shallow, although subordinate flexures within the basin locally increase these dips (e.g. Alsharhan, 1989) and local deformations are also known associated with upwelling of salt diapirs. Bounding the Gulf to the east and north-east lie the Oman Mountains and the Zagros Mountains of Iran, part of the mobile belt of rocks formed by the subduction of the Arabian plate beneath the Eurasian plate along the Makran Subduction Zone since the late Cretaceous (Pascucci et al 2008).

The geological history of the region was dominated by a compressive event that culminated in obduction of the Oman-UAE ophiolite onto the eastern continental margin of the Arabian Platform in the late Cretaceous about 90Ma (million years ago). During this event, the deep water sediments of Triassic to Cretaceous age that had been deposited within the Neotethys Ocean were deformed, forming an imbricate thrust stack several kilometres thick which crops out to the east of Dibba. The shallow water platform limestones, laid down contemporaneously at the margin of the Neotethys Ocean, are less competent and were less influenced by these compressive events. They now form the northern outcrops of the Hajar Mountains.

Obduction of the ophiolite loaded the Arabian Platform margin, leading to crustal flexuring and the development of a foreland basin. This basin whose axis lies roughly north-south between coastal Dubai and the present mountain front, was filled with a largely marine late Cretaceous to Palaeogene sequence up to $3 \mathrm{~km}$ thick (Styles et al, 2006). It is now partially exposed along the western edge of the Hajar Mountains and in large-scale folds such as the Jebal Al Fayah and Jebal Hafit structures.

In Miocene times, from about 23 to $5 \mathrm{Ma}$, a compressive event caused by renewed movement of the Arabian Plate north eastwards culminated in formation of the Zagros Mountains. It also led to uplift of the Hajar Mountains to at least $3 \mathrm{~km}$ elevation (Boote et al, 1990) about $1500 \mathrm{~m}$ greater than the present height of the ophiolite outcrops. As a consequence the sea retreated from most of the foreland basin and a terrestrial environment was established in which rivers flowed from the uplifting Hajar Mountains to form an aerially extensive bajada more than $100 \mathrm{~km}$ from the mountain front. The quantity of clastic sediment in these alluvial fans is principally due to a late Miocene hot and humid climate, with rainfall estimated as about 300mm per annum (Micheels, 2007) a figure 
likely to have been far exceeded in the mountains because of orographic effects. In the western Emirates and Qatar, marine limestones and sabkha sandstones of the Dam and Shuwaihat Formations were laid down on the cratonic side of the foreland basin.

In the Late Miocene to Pliocene times, a fluvial system was also established in the west of the UAE and Saudi Arabia with eastwards draining rivers depositing a sequence of fluvial siliciclastic deposits (the Baynunah Formation) which crop out along the coast west of Abu Dhabi. These rivers drained the eastern part of Saudi Arabia, which had been tilted up following the rifting of the Red Sea around 20Ma. Both these fluvial systems debouched into a restricted basin located between Abu Dhabi and Dubai where thin limestones, sabkha deposits and evaporate-rich mudstones of Miocene age are also known to occur. Figure 2 shows a schematic section illustrating the inferred stratigraphic relationships between the main formations encountered in the region.

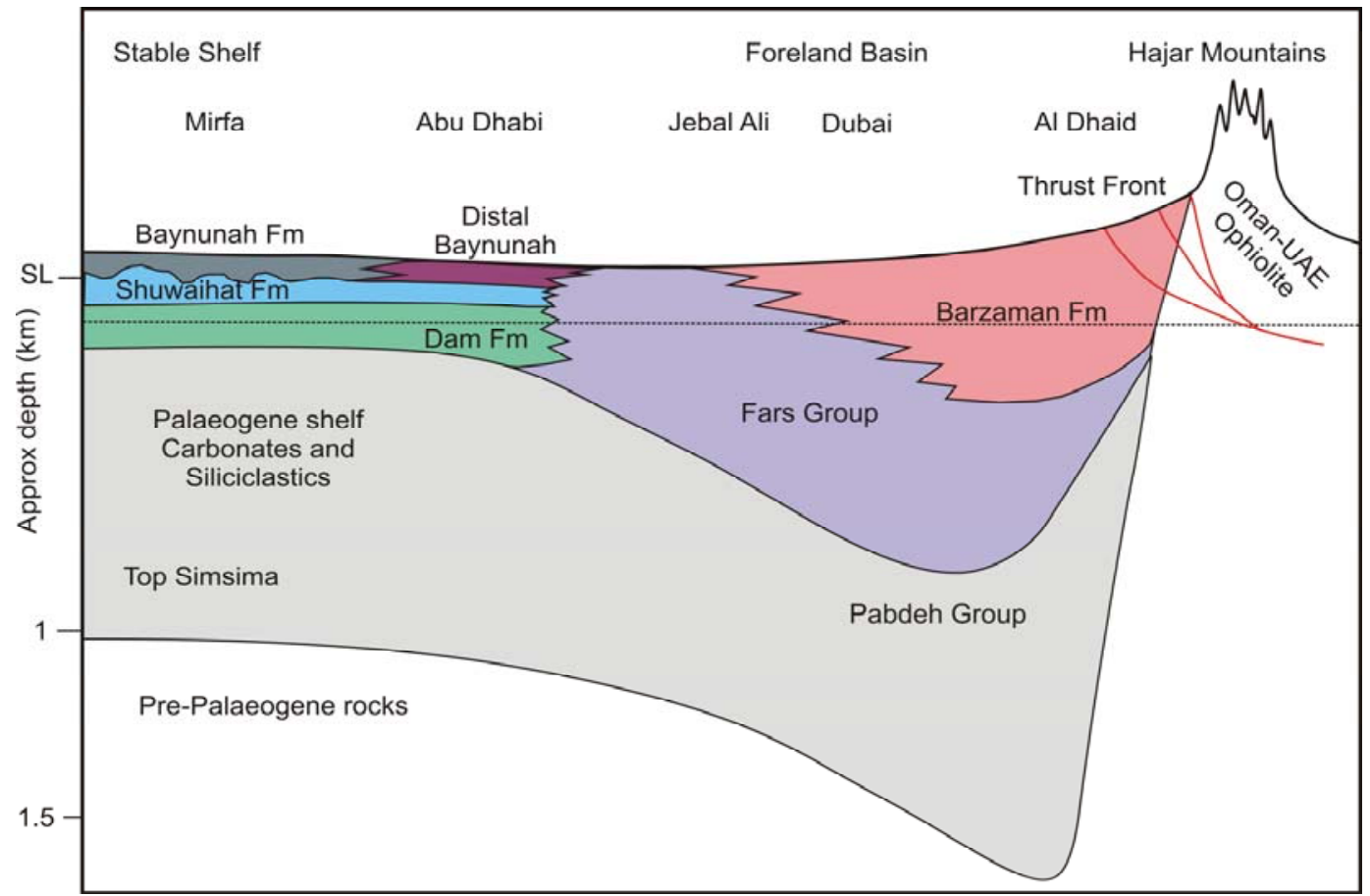

Fig. 2 Schematic interrelationships between principal stratigraphic formations, UAE

The Hajar mountains of the UAE currently consist of three major geological units which have contributed to the clast composition of the Barzaman Formation bajada: limestones of Triassic to early Cretaceous age in the north; deep water chert- rich lime mudstones of probable Jurassic to Cretaceous age in the low hills south of the limestone outcrops; and, the Oman-UAE ophiolite which consists of mafic igneous rocks (largely dunite, harzburgite and gabbro intrusions). On account of the relative durability of the gabbro and chert, these lithologies dominate the clast component of the Barzaman Formation. These and other clasts decrease in size with distance westwards from their source in the mountains. Clasts of ultramafic rocks such as harzburgite are however relatively easily broken down by mechanical weathering and thus are most commonly encountered close to their source in the mountains. 


\section{Field description of the Barzaman Formation}

\section{Outcrop characteristics}

The term "Barzaman Formation" was applied by Maizels (1988) to alluvial fan/wadi channel gravels in the eastern Oman Mountains that were pedogenically altered to calcrete-like deposits to depths of over $200 \mathrm{~m}$. The mechanism for this pedogenic alteration was thought by Maizels to be due to a progressive rise in water table as the wadi fan deposits accumulated over time. Associated with this rise in water table, in situ chemical precipitation of carbonates cemented and altered the original granular deposits .... "to form the calcrete-like deposits of the Barzaman Formation".

The best exposed surface outcrops of the Barzaman Formation occur along a tract extending the length of the mountain front between Al Ain and Al Dhaid to the north. Here, the Barzaman Formation typically forms a series of dissected, flat-topped mesas whose top surfaces dip at less than $5^{\circ}$ to the south west, and ultimately pass beneath dune fields (Styles et al, 2006). The maximum estimated thickness of these surface outcrops is $60 \mathrm{~m}$. Close to the mountain front, the conglomerates weather to form distinctive boulder-clad hills, markedly different in both grain size and lithology from the surrounding Quaternary alluvial fan deposits. The majority of these boulders consist of gabbro with a well developed black desert varnish which, in conjunction with the pale coloured dolomite matrix, gives rise to a highly characteristic complex mottled pattern on the aerial photographs that enables good delineation of the outcrops.

The most common lithology of the eastern outcrops of the Barzaman Formation is a poorly sorted, cobble to boulder conglomerate with clasts largely of harzburgite and gabbro, with minor amounts of metamorphic rocks (red and grey chert and rare limestone). The conglomerates are generally strongly cemented by a secondary creamy-white dolomite and stand proud as weathering resistant outcrops. The coarser conglomerates are characterised by the presence of well rounded to sub-rounded, occasionally angular and brecciated, gravel and cobbles up to $20 \mathrm{~cm}$, with some boulders up to $50 \mathrm{~cm}$ in diameter. The sediment is poorly sorted, generally matrix supported and locally clast supported. The majority of the sediment is un-stratified and does not show obvious clast imbrication (Figure 3). Locally there are beds of loosely-cemented coarse sandstone or granule conglomerate and relatively sporadic sand-dominated beds which may have channelled bed forms. 


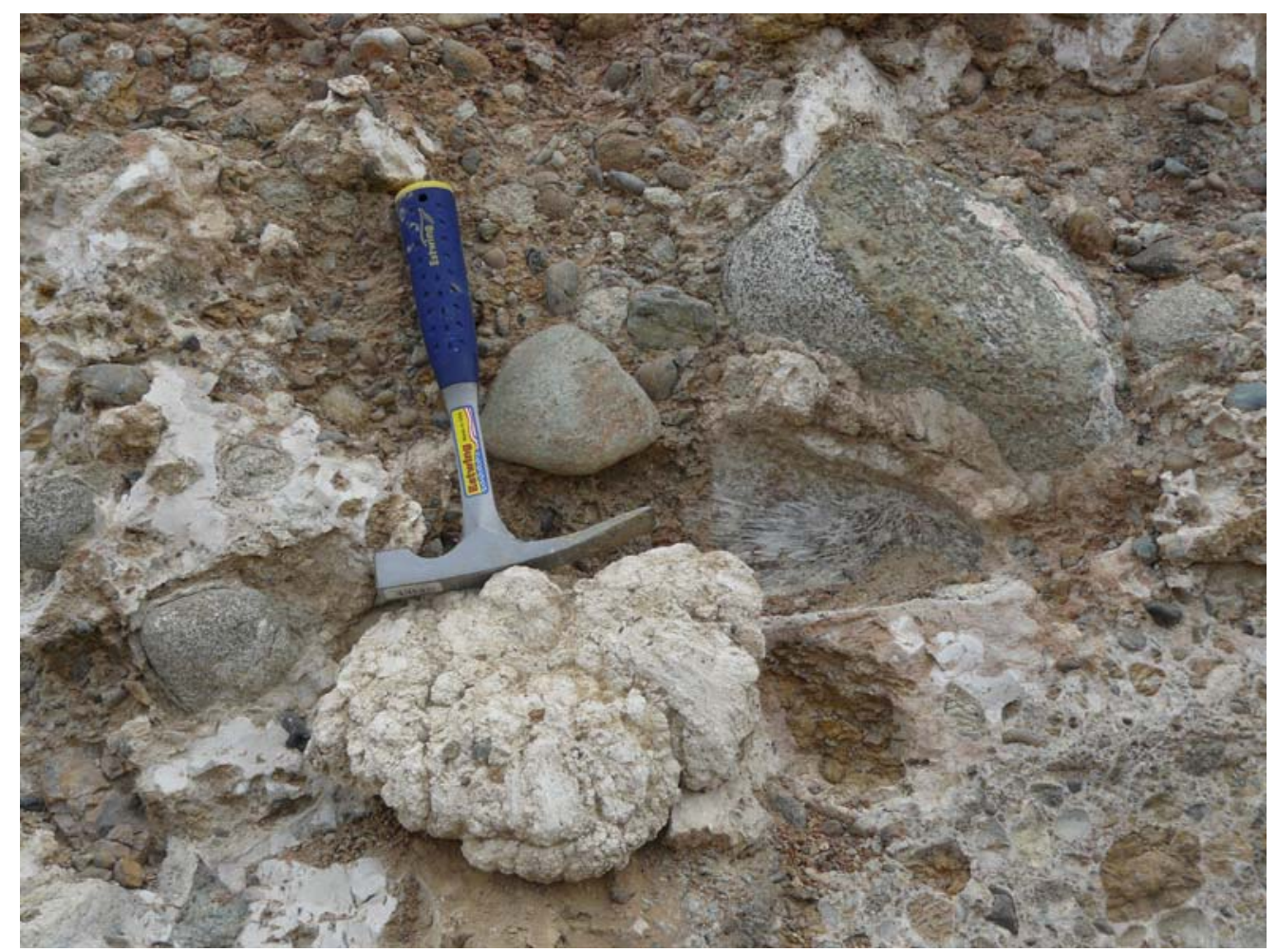

Fig. 3 Proximal conglomerates, Barzaman Formation

The Barzaman Formation lithologies are interpreted as proximal fluvial and alluvial fan deposits laid down in a highly active largely braided stream system.

Instructive man-made exposures of the Barzaman Formation close to the mountain front can be seen just south of Al Dhaid, particularly on the Al Dhaid Shawkah road. Figure 4 shows a section in a road-cutting through the channelized coarse proximal harzburgite and gabbro dominated conglomerates. The larger clasts are dominantly gabbro, set in a finer groundmass of harzburgite. Several discrete channel fill conglomerates can also be identified. Isolated irregular masses, nodules and mammilated concretions of secondary dolomite can be seen, often encompassing the clasts. This locally alters the deposit to a matrix supported conglomerate indicating a volume increase from the original sediment. Slickenfibres occur around some clasts, indicating relative movement of the clast during cement growth. 


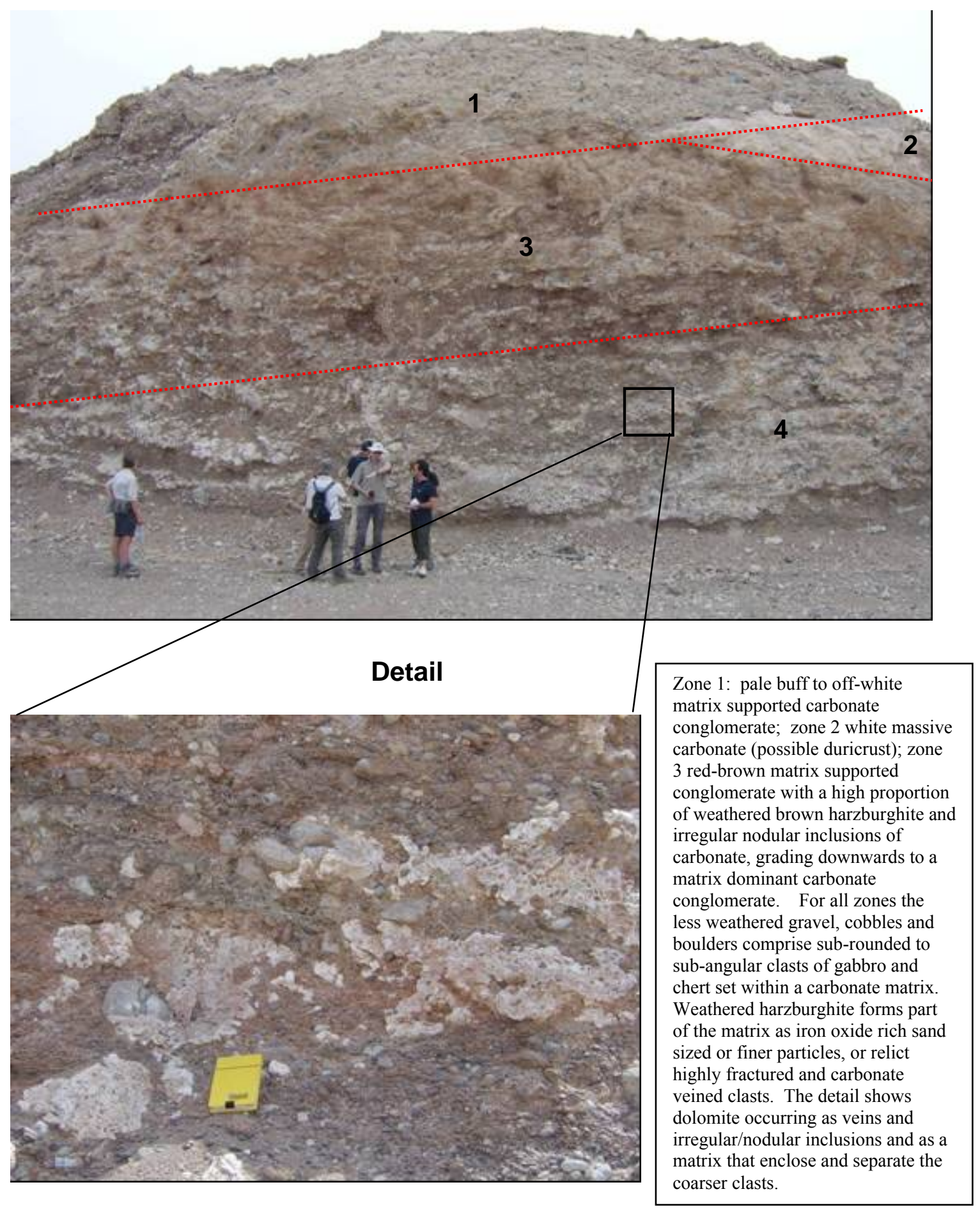

Fig. 4 Exposure in new road cutting near Mahdah, western Oman (UTM 0399649mE, 2700079mN) 
Good exposures of laterally variable, dolomite cemented proximal conglomerates and palaeosol horizons can also be seen in an abandoned quarry near the town of Sha'biyyat Kadrah (Farrant et al., 2006), shown in Figure 5. Here, much of the original sediment has been altered to produce extensive sheets and bodies of dolomite. Two distinct horizons can be identified in this section. The upper zone (Zone 1) comprises a massive mottled reddish brown palaeosol with vertical rhizo-concretions altered to dolomite ${ }^{3}$.

The lower part of the section (Zone 2) shows weathered and altered coarse harzburgite-rich conglomerate. A second dolomite-rich palaeosol horizon occurs at the base of the exposure. These palaeosol horizons are laterally discontinuous as they have locally been cut out by channels of the overlying conglomerate. The top of the section is obscured by quarry spoil.

Between coastal Dubai and the mountain front the Barzaman Formation is largely concealed beneath Quaternary aeolian and fluvial deposits, occasionally cropping out inter-dune areas west of the Fayah Range.

To the west, the Barzaman Formation grades into progressively more distal conglomerates, sandstones and mudstones. It crops out in large inter-dune areas south of Dubai and Jebal Ali, where it weathers out as coarse gravel, often with secondary gypsum. This succession is distinguished from the Quaternary alluvial fan deposits by its finer clast size and composition

Natural sections in the Barzaman Formation in the coastal areas are few, but recent deep temporary excavations and numerous cored boreholes have proved a thick sequence of fining-up conglomerate-calcisiltite beds, locally cut by conglomerate filled channels (Figure 6) and capped by brecciated palaeosols. Here the Barzaman Formation consists of: weathered gabbro and brown ultramafic dominated clast supported conglomerates and sandstones; creamy white matrix supported conglomerates with a dolomite matrix; massive calcisiltites with occasional gabbro, chert and highly weathered brown harzburgite clasts and veins or pods of palygorskite rich green marl; and brecciated dolomitepalygorskite calcisiltite. The thickness of the individual units is of the order of 0.5 to 7 metres.

In the area of the Dubai-Abu Dhabi border, the distal conglomeratecalcisiltite sequence of the Barzaman Formation merges laterally into a sequence of evaporite-rich mudstones (the Fars Group). These consist of thinly bedded and laminated to thick bedded white, red-brown and greenish grey carbonate siltstone and marl, with thin inter-beds of polymictic conglomerate and massive gypsum. The succession in this area is interpreted as distal alluvial fan deposits composed of interbedded conglomerate, sandstone and clay-rich dolomite mudstone units with sporadic clasts of ophiolite origin and chert.

The Barzaman Formation regionally is thus interpreted as proximal fluvial and alluvial fan deposits laid down in a highly active largely braided fluvial system which prograded into the foreland basin as far west as Ghantoot.

\footnotetext{
${ }^{3}$ Palaeosols occur locally in relatively fine grained parts of the succession. They are characterised by a sub-vertical fabric within crudely nodular dolomite which may be reddish stained and contain rootlet horizons. In places the palaeosols are up to 1metre thick and gently folded, presumed due to volume change during development of the dolomite cement. Similar tube-like rhizomes have been reported by Cobanoglu et al (2008) in caliche deposits formed on ophiolite bearing gravels in Turkey.
} 


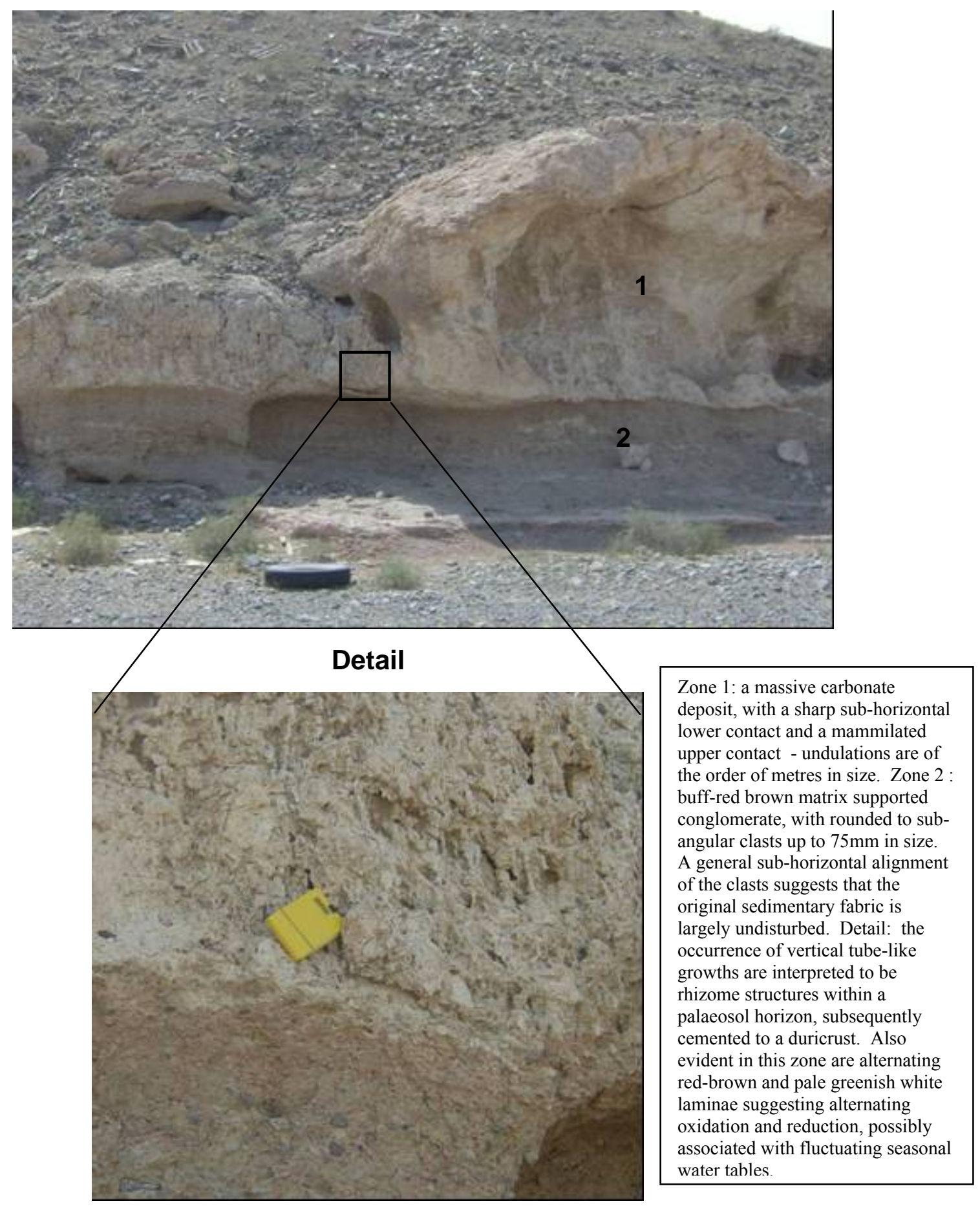

Fig. 5 Barzaman Formation exposure in an old quarry near Sha'biyyat Kadrah (truck tyre for scale in upper photo, $20 \mathrm{~cm}$ long notebook in detail) 


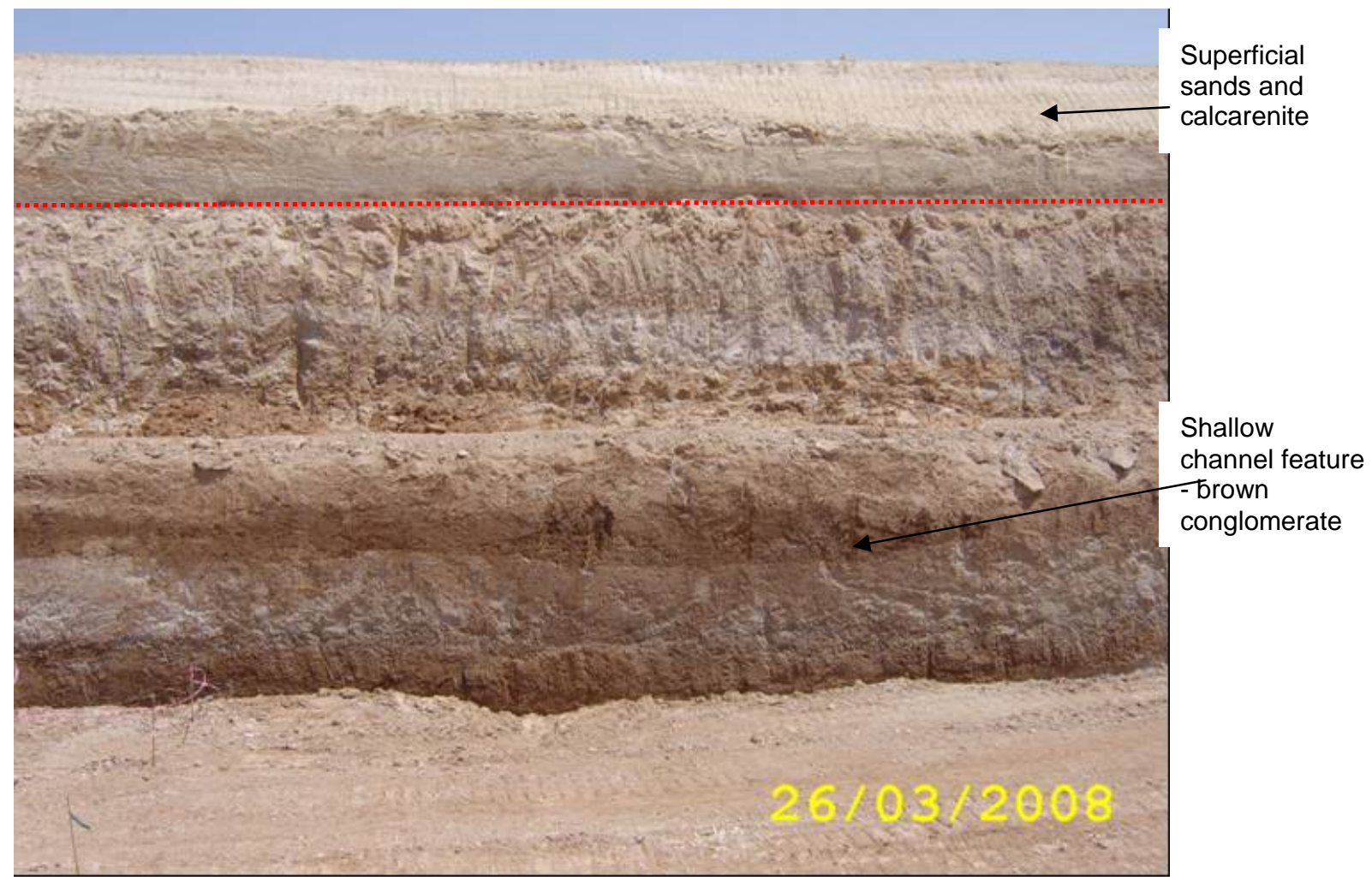

Fig. 6 Barzaman Formation beneath Pleistocene Calcarenite and Holocene aeolian sand, coastal excavation, Dubai. The height of the excavation is approximately $10 \mathrm{~m}$.

\section{Diagenetic alteration}

A highly distinctive feature of the Barzaman Formation is the extensive diagenetic alteration of the original sediments due to dolomitisation. This is manifested by a range of features from minor alteration along bedding planes and fractures, irregular pods, cumuliform and mammilate masses of dolomite several metres in diameter, to more pervasive stratiform lenses and beds of creamy white dolomite rock. These cemented areas often stand proud as resistant outcrops.

The replacement process has altered the clasts and the matrix of the sediments, resulting in "ghost" harzburgite clasts and areas of pink ferruginous staining representing former clasts. The secondary growth of dolomite in the matrix has changed the fabric from clast supported to matrix-supported conglomerate (Figure 7). 


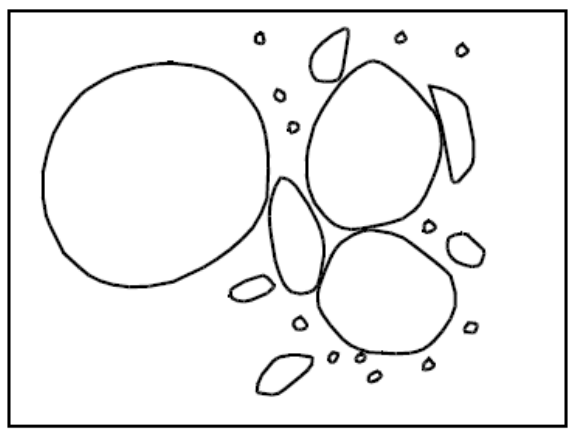

1. INITIAL DEPOSITION

Poorly sorted fluvial deposits

Predominantly clast supported deposit

Dominated by well-rounded gravels
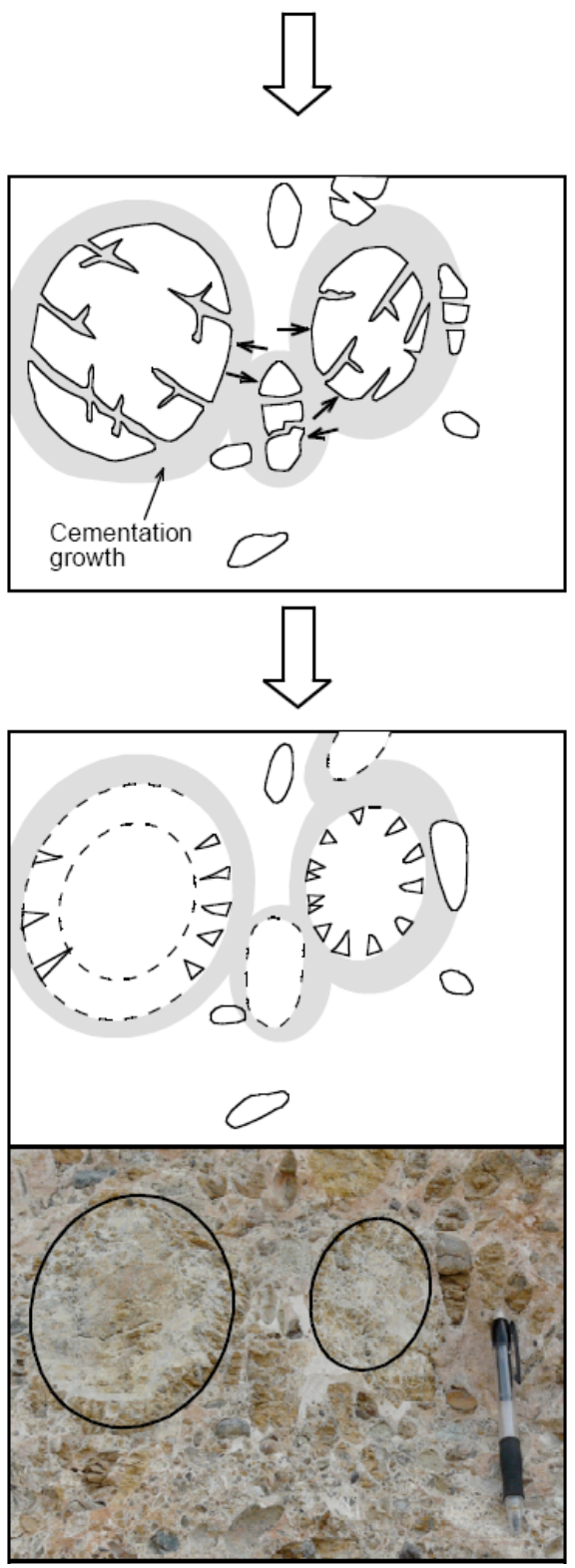

\section{ADVANCED PEDOGENESIS}

Breccia.

Matrix supported.

Gravel fragments range from well-rounded to sub-angular.

Carbonate cementation - principally dolomite. Ghosting of original larger gravel clasts.

More advanced pedogenesis can lose nearly all gravel clasts.

\section{NOTES:}

Considerable lateral \& vertical variation in pedogenic brecciation, depending on groundwater supply. Highly brecciated zones may occur close to relatively unaltered deposits.

Fig. 7

Schematic showing inferred mechanism of alteration, replacement and cementation of the Barzaman Formation 
Well developed slickensides can often be seen surrounding individual clasts which have been rotated, shattered or displaced during this alteration. In some cases these features have developed into "micro-faults" possibly due to differential volume changes during cement growth (Figure 8).

In the more distal parts of the Formation around Dubai, much of the deposit has been altered to a distinctive creamy white-grey dolomite and palygorskite-rich mudstone and siltstone ("calcisiltite") with relict clasts of highly altered harzburgite, gabbro and chert. Brecciated horizons also occur where the dolomite-rich mudstone has undergone in-situ brecciation, possibly due to pedogenic alteration.

The extensive dolomitisation has most likely developed due to highly alkaline magnesium-rich ground-waters derived from the Oman-UAE ophiolite. The groundwater associated with this bajada system and the climatic variation in the past $10 \mathrm{Ma}$ or so, has had a profound influence on geochemistry of the matrix of these sedimentary successions. Extensive fluid-rock interaction has caused preferential chemical alteration of smaller clasts and given rise to concentric alteration rims around individual larger clasts. The dissolution of silicate minerals (particularly in the ophiolite lithologies) results in simultaneous precipitation of clay (principally palygorskite and minor kaolinite) and/or iron oxides.

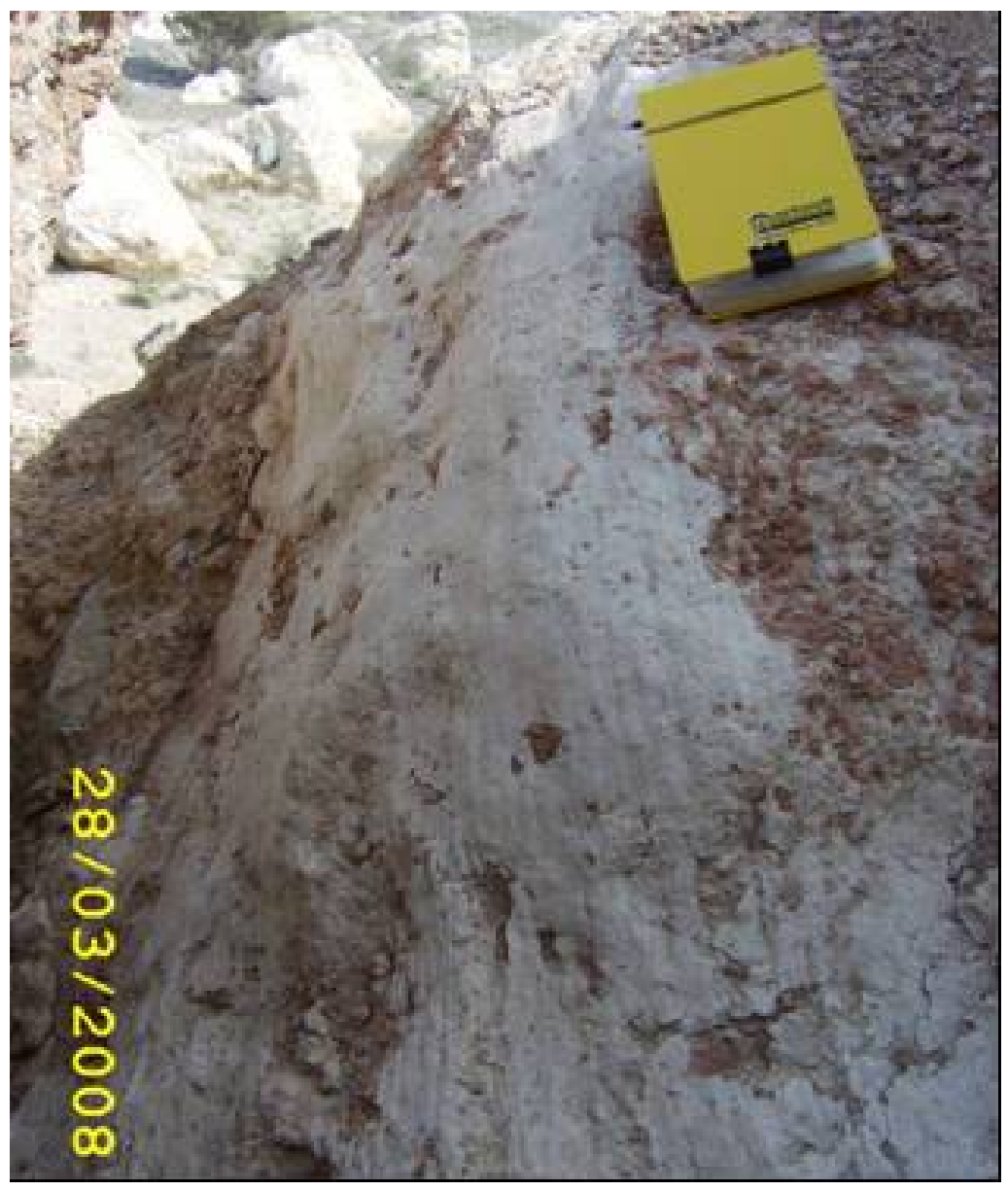

Fig. 8 Slickensided "micro-fault" in exposure near Sha'biyyat Kadrah 
Field and laboratory observations indicate that in some discrete layers of rock within the Barzaman Formation, the carbonate content is dominated by calcite rather than dolomite ${ }^{4}$. Palygorskite is also present in these strata, although they typically display higher uniaxial compression strengths than the strata dominated by dolomite.

\section{Borehole cores}

In routine ground investigations in Dubai, geotechnical logs are typically compiled using the British Standard BS5930:1999 (pre Amendment 1, 2007) and the descriptive terms for carbonate rich lithologies are based upon the scheme proposed by Clarke \& Walker (1977). Subsequent descriptions used in this paper will generally follow these standard approaches for consistency with local practice; however, suggestions are made in below for an improved application of the Clarke \& Walker scheme; a simple lithological classification scheme based on the principal components of this formation as seen in hand specimen is also proposed.

In any typical borehole core drilled through the Barzaman Formation four basic rock types occur repeatedly in the sequence, namely:

1. a brown conglomerate, composed of a high proportion of variably weathered mafic and ultramafic rock gravel and sands within an iron oxide, fine grained carbonate and/or green marl matrix forming a minor constituent (Figure 9);

2. a matrix supported conglomerate, where the clasts are a minor proportion of the rock and the white carbonate/marl matrix is dominant (Figure 9);

3. a mottled buff white indurated fine grained to micritic marl ${ }^{5}$ ("calcisiltite or calcilutite" after Clarke \& Walker, 1977), where the mottling is evident as a red-brown or green colouration and there are virtually no intact clasts visible (Figure 10); and,

4. a breccia, where angular fragments of the calcisiltite/calcilutite may be found within a matrix of high plasticity green $\operatorname{marl}^{6}$ (Figure 10).

\footnotetext{
${ }^{4}$ Similar formations have been studied in Kuwait for instance (Khalaf and Abdal, 1993) and were considered to be formed by the de-dolomitisation processes of dissolution and/or replacement. Stahr et al (2000) describe the development of palygorskite and calcite duricrusts in Tertiary sand and gravel deposits in Southern Portugal, thought to have formed in a $\mathrm{n}$ intermittent playa-lake in a semi-arid, seasonal climate.

${ }^{5}$ The term "marl" is applied to a variety of clay-carbonate composition rocks in the literature, however a widely used definition is that according to Fookes \& Higginbottom (1975), where a "marlstone" is a carbonate rock with over 35\% clay. Mineralogical tests on the mottled white calcisiltite indicate typically up to $20 \%$ clay content (predominantly palygorskite) so the carbonate matrix of the conglomerates would fall within the "limey marlstone to marly limestone" classification of Fookes \& Higginbottom. However the dominant carbonate mineral is dolomite so "marly dolostone" or "dolomitic marlstone" may be more appropriate terms although there are significant variations in the proportions of dolomite-calcite.

${ }^{6}$ Mineralogical tests carried out on this material indicates that the green marl is composed of much higher proportions of palygorskite clay (up to 50\%). The dolomite occurs as discrete crystals and clusters within the clay matrix.
} 


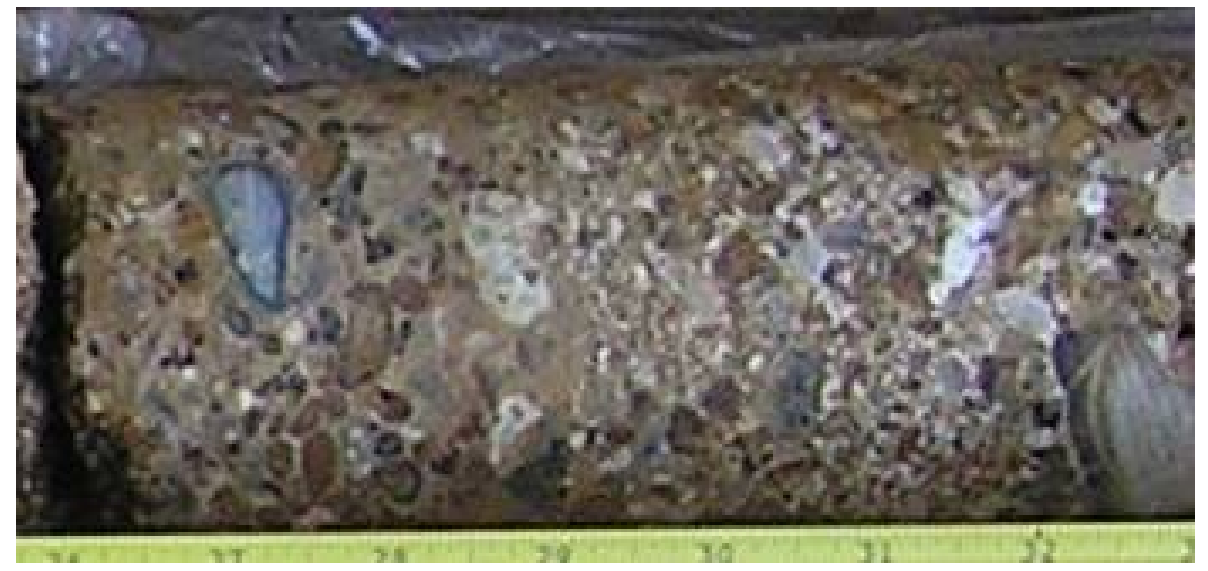

Moderately weak, mottled red brown white, rounded to subangular fine to medium gravel of highly weathered harzburgite, slightly weathered red and green chert, calcisiltite and gabbro (70\%) in a matrix (30\%) of weathered harzburgite sand and silt and (dolomitic) calcisiltite, brown carbonate CONGLOMERATE. Proportion of non-carbonate: carbonate clasts is approximately 90:10. $10 \% \mathrm{HCl}$ test: Calcisiltite matrix - weak reaction.

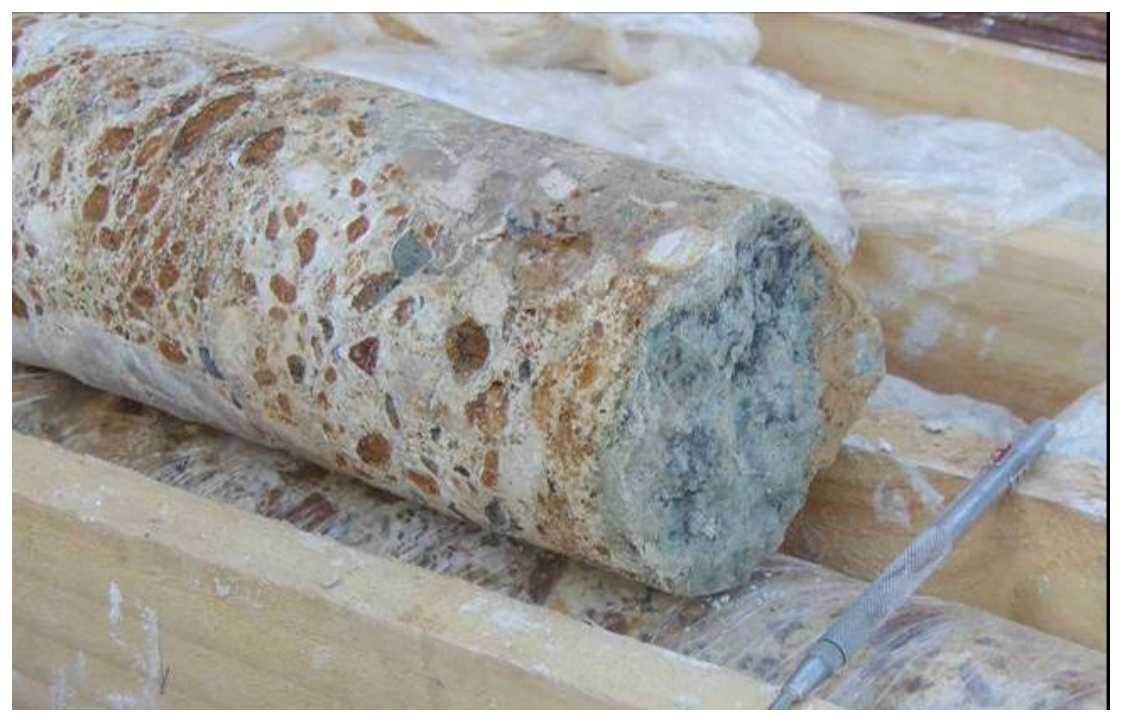

Moderately weak, mottled brown greenish-white, rounded to subangular fine gravel to cobbles of highly weathered harzburgite, slightly weathered red and green chert, calcisiltite and gabbro (75\%) in a matrix $(25 \%)$ of calcisiltite, (dolomitic) white carbonate CONGLOMERATE. Occasional veins up to $10 \mathrm{~mm}$ thick of high plasticity green silt/siltstone. Proportion of non-carbonate: carbonate clasts is approximately 50:50. 10\% $\mathrm{HCl}$ test: Calcisiltite matrix - weak reaction.

Fig. 9 Typical descriptions of main Barzaman Formation conglomerate lithologies (to BS5953:1999, pre-Amd 1) 


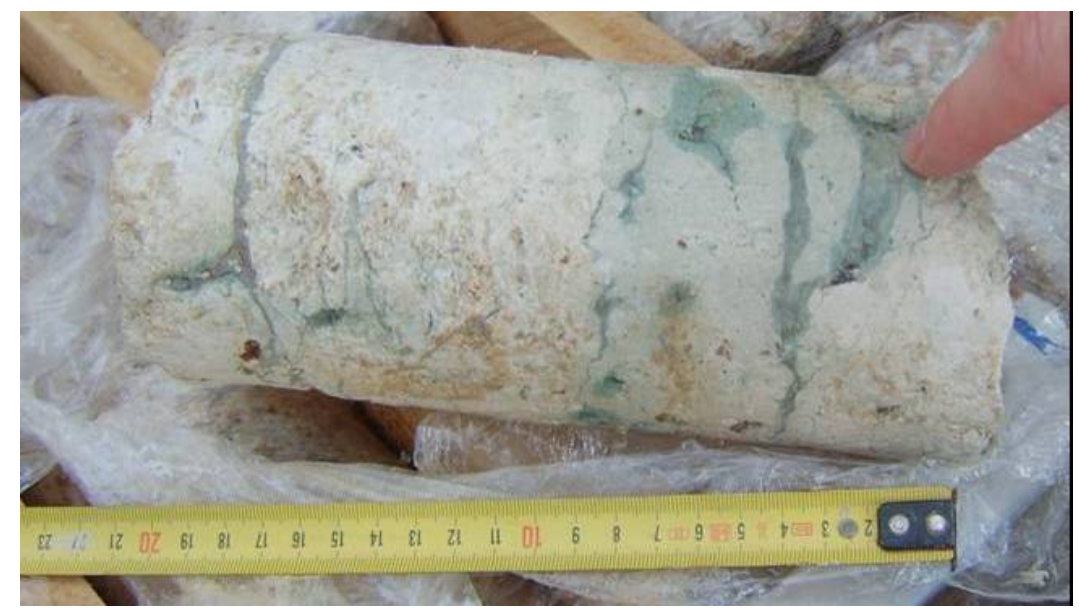

Weak to moderately weak, mottled greenish-white, and possibly brecciated, (dolomite rich) CALCISILTITE/calcilutite. Occasionally small bedding parallel vugs $(<5 \mathrm{~mm})$, veins and inclusions up to $10 \mathrm{~mm}$ thick of high plasticity green marl. $10 \% \mathrm{HCl}$ test: Calcisiltite matrix negligible reaction.

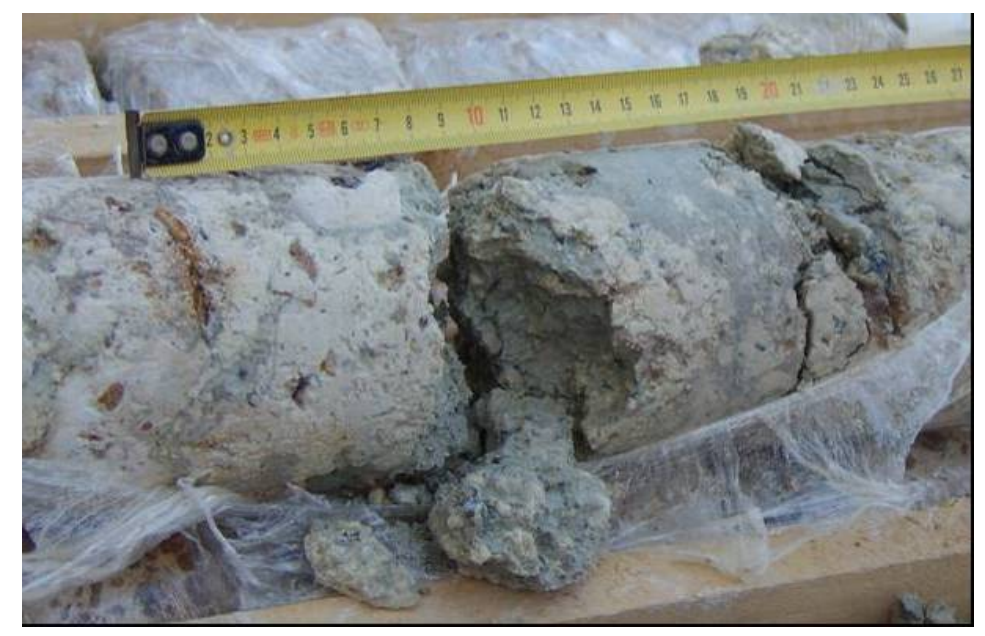

Very weak/friable to weak, mottled greenish-white, brecciated, predominantly comprising subangular clasts of calcisiltite up to $100 \mathrm{~mm}$ in size in a matrix of high plasticity green marl, (dolomite rich) carbonate BRECCIA. Note thin $(<1 \mathrm{~mm})$ irregular veins of black manganese oxide in calcisiltite fragments. $10 \% \mathrm{HCl}$ test: on green silt and white calcisiltite fragments negligible reaction.

Fig. 10

Typical descriptions of main Barzaman Formation "calcisiltite" lithologies (to BS5953:1999, pre-Amd 1) 
Within the conglomerates we have found a wide variety of clasts in various weathering states - from relatively un-weathered, angular to sub-angular red and green chert, to partially weathered rounded to sub-rounded gabbro clasts to highly weathered rounded to sub-rounded to disintegrated ultramafic clasts thought to be of harzburgite composition.

The carbonate-marl/calcisiltite which occurs both as continuous sections of core and as matrix within the conglomerate is often mottled brown and green from the field observations of Maizels (1998) and Abrams \& Chadwick (1994), the brown mottling may in many instances reflect "ghosts" of completely weathered harzburgite clasts. The colour mottling is considered to be primarily related to variations in clay and oxide content in the rock. The calcisiltite matrix also displays some vuggy sections, evidence for feint laminations and faint to distinct evidence of brecciation. These fabrics are interpreted to reflect authigenic growth of the "calcisiltite" cements.

Simple $10 \% \mathrm{HCl}$ acid tests have been carried out on drill core samples during logging by the authors - this test can give an indication of the relative proportions of dolomite and calcite in the rock by adopting a simple classification such as the four-class approach of Burnett and Epps (1979). Whilst the original classification was based upon immersion of chips in a beaker of dilute acid in the laboratory, we consider that with slight modifications (see Table 2) the classification has provided a useful field test to classify the rock in terms of relative proportions of dolomite and calcite. In applying this test we have found that the majority of cores through the Barzaman Formation are either weak to negligible reaction suggesting that the calcisiltite is in fact a dolomitic rich rock in most cases. The discrete calcite rich zones described above are also readily identified using this field test.

\begin{tabular}{|c|c|c|}
\hline \multicolumn{2}{|c|}{ Proposed reaction description when tested on core } & Suggested descriptor \\
\hline Strong & $\begin{array}{l}\text { Vigorous effervescence, clearly } \\
\text { audible, rapid reaction }\end{array}$ & Calcite rich \\
\hline Moderate & $\begin{array}{l}\text { Brisk, quiet effervescence, audible, } \\
\text { moderately fast reaction }\end{array}$ & Calcareous \\
\hline Weak & $\begin{array}{l}\text { Mild effervescence, small bubbles } \\
\text { formed, slow reaction, faintly } \\
\text { audible when held close to ear }\end{array}$ & Dolomitic \\
\hline Negligible & $\begin{array}{l}\text { Negligible effervescence, no or very } \\
\text { few obvious bubbles, not audible }\end{array}$ & Dolomite rich \\
\hline
\end{tabular}

Table 2 Reactivity to $10 \%$ dilute $\mathrm{HCl}$ (Burnett \& Epps, 1979), with proposed simplifications for core logging in the Barzaman Formation 


\section{Mineralogy and micro-structure}

\section{Introduction}

Clarke \& Walker noted in their 1977 technical note that:

'the most frequently occurring alternative to calcite is likely to be dolomite.....' and '...from laboratory analysis using infra-red spectroscopy, the clay mineral content appears to be predominantly attapulgite and polygorskite (sic) of the highly plastic sepiolite group'.

In describing the characteristics of the Barzaman Formation in Oman, Maizels (1988) noted the dominance of dolomite within "whitish pink massive indurated rock" (interpreted here to be equivalent to the "calcisiltite") and significant proportions of clay minerals, including illite, montmorillonite and possibly palygorskite. Abrams \& Chadwick (1994) also noted the presence of "ghosts" of relict ultramafic clasts visible within the white matrix of these rocks - and considered that they had undergone diagenetic alteration to clay rich minerals. Figure 11 shows one such feature taken from a cored borehole from coastal Dubai, embedded within a green high plasticity marl vein.

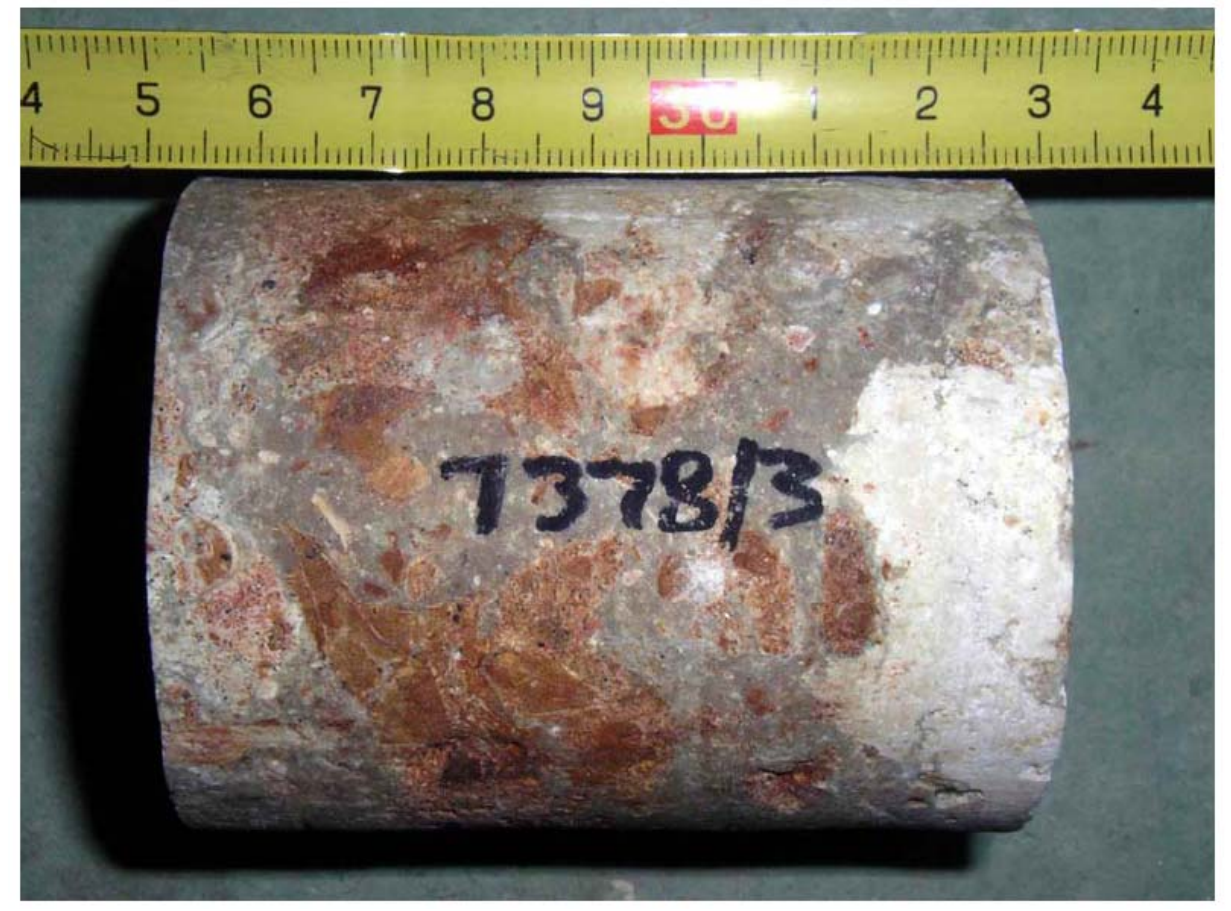

Fig. 11 Core surface showing a fragmented relict ultramafic clast in a green marl matrix (Image courtesy GMRS)

Tests carried out for the authors on samples of the calcisiltite, weathered brown clasts and also on the green marl indicate that the rock is largely composed of dolomite and the hydrated magnesium-aluminium silicate clay mineral 
palygorskite $^{7}$. Calcite locally replaces dolomite as the principal carbonate mineral.

Palygorskite is associated with low latitudes and semi-arid climates (Callen 1981) and is believed to form in high temperature and salinity conditions in continental-lacustrine to marine environments (Singer 1979). Palygorskite is found with chert, dolomite, limestone and other non-detrital sedimentary rocks (Isphording 1973). It weathers to smectite when mean annual rainfall is greater than 300mm (Paquet \& Millot 1972).

Other investigations in the Arabian Gulf Region suggest similar settings for the occurrence of palygorskite clay. Aiban $(2006,2007)$ observed palygorskite coated gypsum in eastern Saudi Arabia that suggested precipitation from hypersaline solutions during dry intervals. Cagatay (1990) investigated the occurrence of palygorskite in the Dammam Dome, eastern Saudi Arabia and suggested that the palygorskite was authigenic forming in a marginal restricted basin during Palaeocene-Middle Eocene time. Aqrawi (1993) investigated the origin of Palygorskite in southern Mesopotamia and identified it to be authigenic and associated with dolomite and gypsum, formed in a hypersaline, alkaline $\mathrm{pH}$ and $\mathrm{Mg}$-rich environment.

Palygorskite $\left.(\mathbf{( M g}, \mathbf{A l})_{5} \mathbf{S i}_{8} \mathbf{O}_{20} \mathbf{( O H}\right)_{2}\left(\mathbf{O H}_{2}\right)_{4} \cdot \mathbf{4 H}_{2} \mathbf{O}-$ Ciullo, 1996) is a member of the palygorskite and sepiolite (formerly hormite) clay mineral group of phyllosilicates which include attapulgite (Anthony et al, 2001). Palygorskite and sepiolite are hydrated magnesium aluminium silicates, with palygorskite representing the low-magnesia end member and sepiolite the high-magnesia end member.

The mineral comprises tetrahedral silicon-oxygen molecules arranged together to form a "sheet" tetrahedral layer and octahedral aluminiummagnesium-hydroxyl molecules arranged together to form a sheet octahedral layer. These two layers are combined as two tetrahedral sheets with one octahedral sheet to form a single lattice (i.e. a 2:1 sheet silicate). However, the palygorskite group minerals differ from other 2:1 sheet silicates (such as montmorillonite) in that the octahedral sheets are not continuous but form alternate ribbons of $2: 1$ sheet silicate structures. As a result of the ribbon-like crystal structure rectangular channels run parallel to the $\mathrm{x}$-axis between opposing 2:1 ribbons (Figure 12 - after Galan 1996).

This characteristic of the crystal structure is expressed in a microscopic habit comprising interwoven mats or bundles of needle-like fibres. It is in the channels that charge balancing ions such as water may be attracted resulting in dispersion of the fibrous mats or bundles of fibres to yield a randomly intermeshed network of fibres (Galan 1996).

Palygorskite has a high specific surface area of 400 to $600 \mathrm{~m}^{2} / \mathrm{gram}$, similar to the 2:1 swelling clay montmorillonite which has a specific surface area of 200 to $800 \mathrm{~m}^{2} /$ gram (Whitlow1990). However whilst palygorskite has a Cation Exchange Capacity (CEC) of 4 to $40 \mathrm{mEq} / 100 \mathrm{~g}$ (Galan, 1996), this is considerably lower than typical CEC values of $100 \mathrm{mEq} / 100 \mathrm{~g}$ for montmorillonite and similar to low swell potential clays such as kaolinite and illite $(5$ and $30 \mathrm{mEq} / 100 \mathrm{~g}$ respectively).

\footnotetext{
${ }^{7}$ Named after the town of Palygorskaya near the Popovka River, Perm - Ural Mountains in Russia (Anthony et al, 2001).
} 


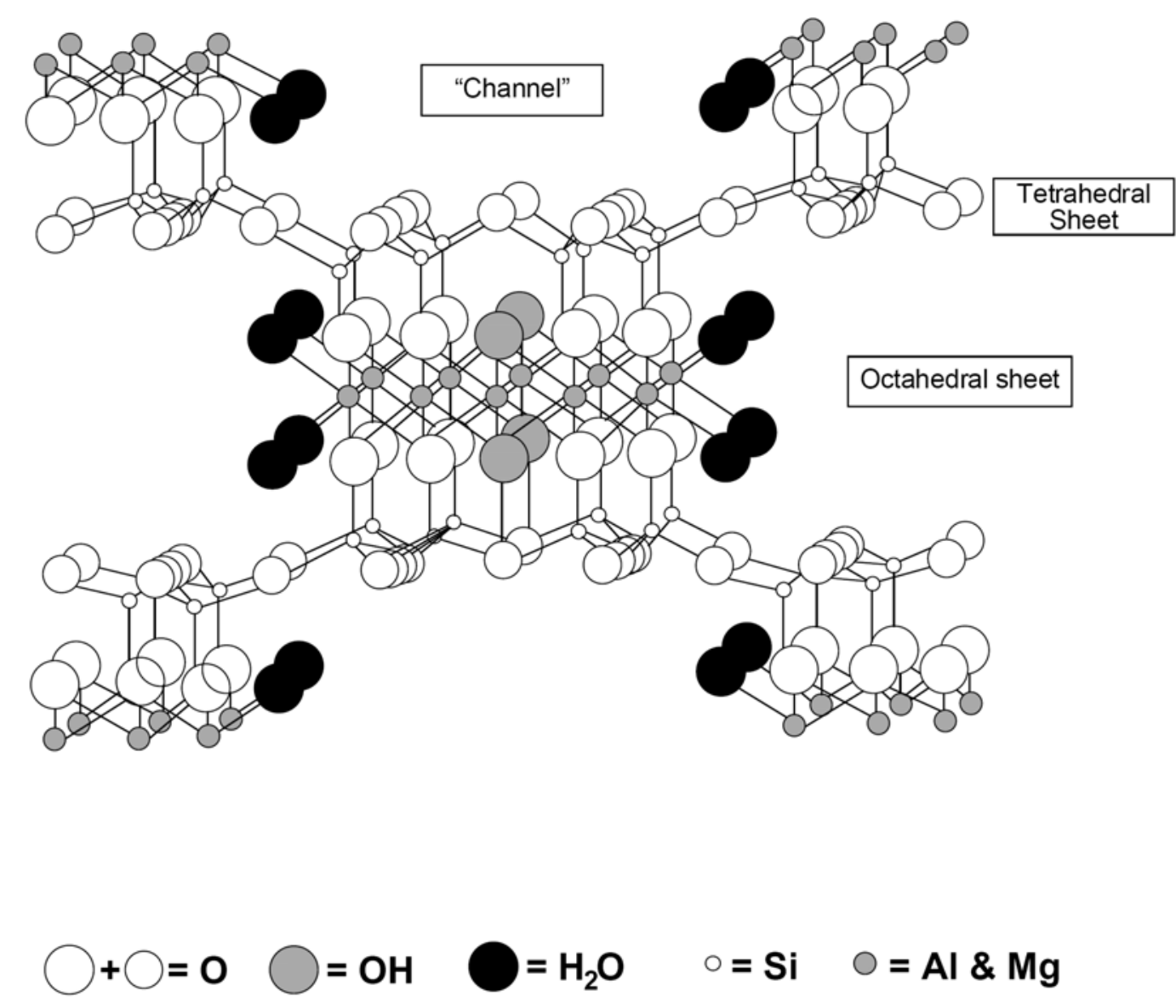

Fig. 12

"Ball and stick" diagram of the atomic structure of Palygorskite (after Galan, 1996)

Rodriguez-Navarro et al (1998) carried out experiments on a limestone containing some $10 \%$ sepiolite and palygorskite. Upon wetting, they inferred that the observed swelling behaviour was caused by inter-particle adsorption of water molecules at the clay-water interface, rather than the more typical intra-particle swelling (i.e. hydration or crystalline swelling) by absorption of water molecules between 2:1 layers such as in montmorillonite. That is, the inter-particle swelling was thought to be due to repulsion between adjacent clay fibres, disrupting the orientation and packing of the clay mats or bundles, rather than by expansion of the crystal lattices. The palygorskite swelling process was also thought to be enhanced when sodium salts were present.

On account of the "channels" and fibrous morphology of the individual strands of the mineral, the principle mechanism for swelling and softening of the clay is inferred to be due to inter-particle repulsion and loss of integrity of the bundles/mats when exposed to water. It is these properties that make palygorskite clays highly absorptive (hence useful for industrial applications) but also susceptible to dispersion, softening and swelling.

In order to investigate the microstructure and mineralogy of the Barzaman Formation lithologies, representative samples were selected for tests at commercial testing laboratories and universities in the UK. The samples were taken from borehole cores at various depths at two sites in Dubai. Site $1-$ adjacent to Dubai Creek and Site 2 - in the Al Bawadi development area in southern Dubai. 
Testing on samples from both sites principally comprised X-ray diffraction (XRD) to assess the mineral constituents of the rock and the potential activity of the clay fraction. Additional tests comprising scanning electron microscopy (SEM) and mercury intrusion porosimetry (MIP) were undertaken on samples from Site 1. The SEM scans carried out on one sample from Site 1 at $55 \mathrm{~m}$ depth (Sample 1B) comprised polished surfaces, major element mapping and broken surface imagery.

\section{Site 1 - adjacent to Dubai Creek}

Three samples of rock core of $60 \mathrm{~mm}$ diameter, obtained using double-tube wireline drilling and Guar Gum polymer drilling fluid, were tested from the Barzaman Formation at this site. The ground conditions comprised a variable cover of Made Ground, aeolian sand, sands of lagoonal and intertidal origin and thin and discontinuous lenses of amorphous peat. These deposits are underlain by Pleistocene calcarenite (carbonate sandstone) and aeolianite (quartzose sandstone), in turn overlying the Barzaman Formation. The tests in the Barzaman Fm yielded the following results:

1. Sample 1A - taken at a depth of approximately $40 \mathrm{~m}$, this sample comprised an high plasticity stiff to hard $^{8}$ green marl vein within mottled and brecciated carbonate siltstone/breccia. The XRD results indicated the following mineral proportions: dolomite $=57 \%$; palygorskite $=35 \%$; halite $=5 \%$ and quartz $=3 \%$.

2. Sample 1B - taken at a depth of approximately $55 \mathrm{~m}$, this sample comprised the mottled and brecciated moderately weak calcisiltite matrix of a white conglomerate. The XRD results indicated the following mineral proportions: dolomite $=83 \%$; palygorskite $=15 \%$; halite $=2 \%$ and quartz $=$ trace.

3. Sample 1C - taken at a depth of approximately $50 \mathrm{~m}$, this sample comprised a brown relict ultramafic clast within a green marl matrix (part of a carbonate conglomerate). The XRD results indicated the following mineral proportions: dolomite $=33 \%$; goethite $=22 \%$; palygorskite $=$ $12 \%$; kaolinite $=10 \%$; halite $=6 \%$; talc $=6 \%$; chlorite $=4 \%$; amphibole $=3 \% ; \mathrm{k}$-feldspar $=2 \%$; quartz $=2 \%$. The presence of chlorite, talc and amphibole would suggest that the clast is a pseudomorph of a diagenetically altered rock of originally mafic to ultramafic composition.

Polished surface examinations on Sample 1B revealed the dominance of dolomite making up the matrix of the rock, but with zones where dolomite occurred as disseminated crystals within a clay matrix (Figure 13). Elsewhere concentrations of clay occur as thin veins. In addition, larger scale voids, sometimes containing halite, could be seen. These are thought to represent both natural porosity and also desiccation cracks associated with drying and shrinkage of the more clay rich parts of the rock. Major element analysis (magnesium, silicon and chlorine) also indicated that magnesium (occurring both in palygorskite and dolomite) was uniformly distributed throughout the area examined. The distribution of chlorine indicated the presence of halite $(\mathrm{NaCl})$ while silicon reflects the distribution of sheet silicate (clay) minerals.

\footnotetext{
${ }^{8}$ Strength descriptions used in this paper refer to BS5930: 1999 (pre Amendment 1, 2007).
} 


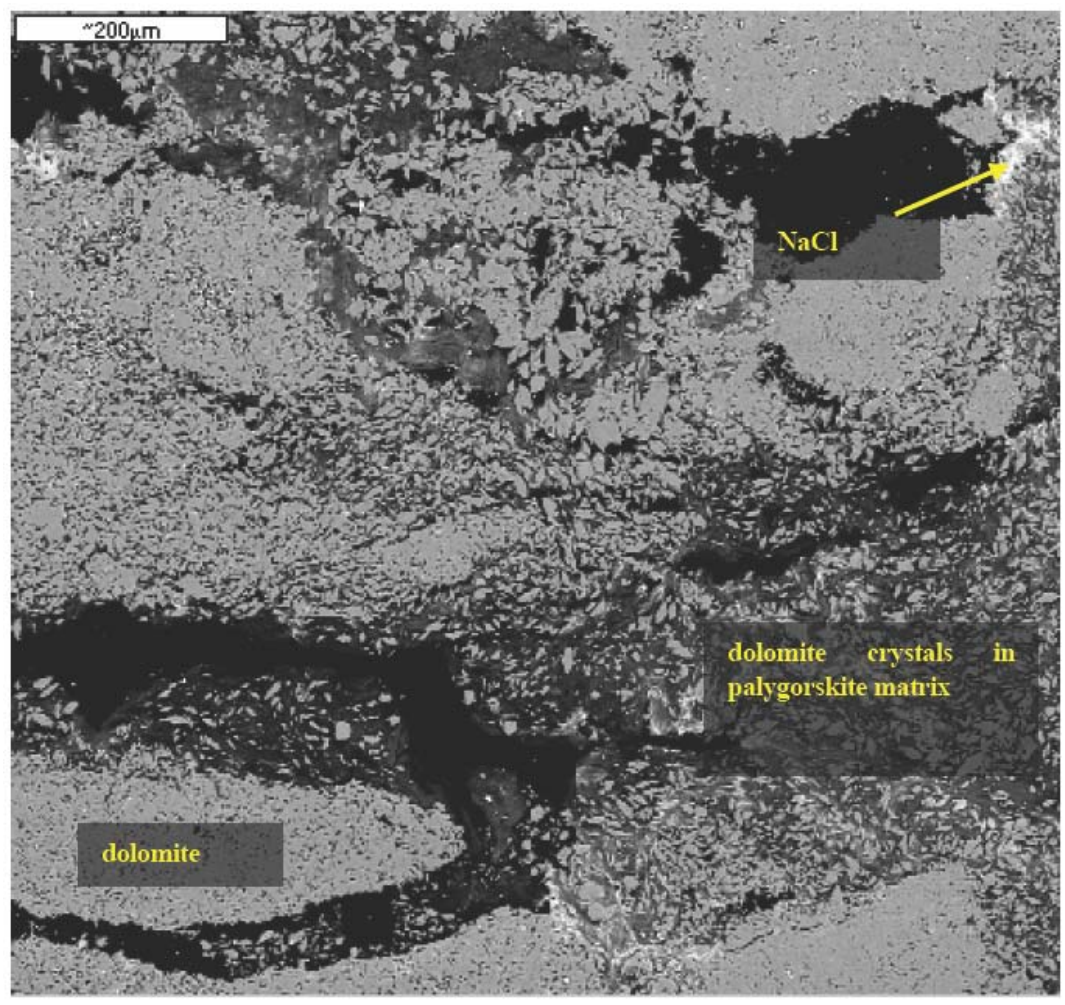

Fig. 13 Sample 1B - polished surface examination showing possible desiccation cracking voids (black areas) and areas of dolomite only, and dolomite disseminated within a palygorskite matrix. Halite occurs on the fringes of some voided areas (Image courtesy GMRS)

Figure 14 comprises a broken surface image which provides data on the interrelationship between the different mineral species, as well as the nature of porosity in the rock. The distinct rhomb-shaped crystals of dolomite can be seen, as well as the mats and fibres of the palygorskite clay. The palygorskite crystals occur as very slender, fibrous crystals typically $<1 \mu \mathrm{m}$ in diameter and sometimes $>20 \mu \mathrm{m}$ long. The palygorskite also appears to act as a matrix to the dolomite crystals in the field of view. Voids between the intertwined crystals represent the micro-scale porosity of the rock.

\section{Site 2 - Al Bawadi development area, southern Dubai}

Three samples of drill core were selected from the Barzaman Formation at a site in southern, coastal Dubai. Rock core of approximately $80 \mathrm{~mm}$ diameter was obtained using double-tube wireline drilling techniques. Guar Gum polymer was used as the drilling fluid. The ground conditions at this site comprise some $3 \mathrm{~m}$ of superficial aeolian sands, overlying some $10 \mathrm{~m}$ of variably indurated thinly bedded calcareous sandstone, overlying some $20 \mathrm{~m}$ of interbedded-brown silica rich and gypsiferous sandstone and polymictic conglomerate (possible Pleistocene aeolian and alluvial deposits). A sharp contact was then seen with underlying calcisiltite, breccia and conglomerate of the Barzaman Formation at approximately $33 \mathrm{~m}$ depth. 


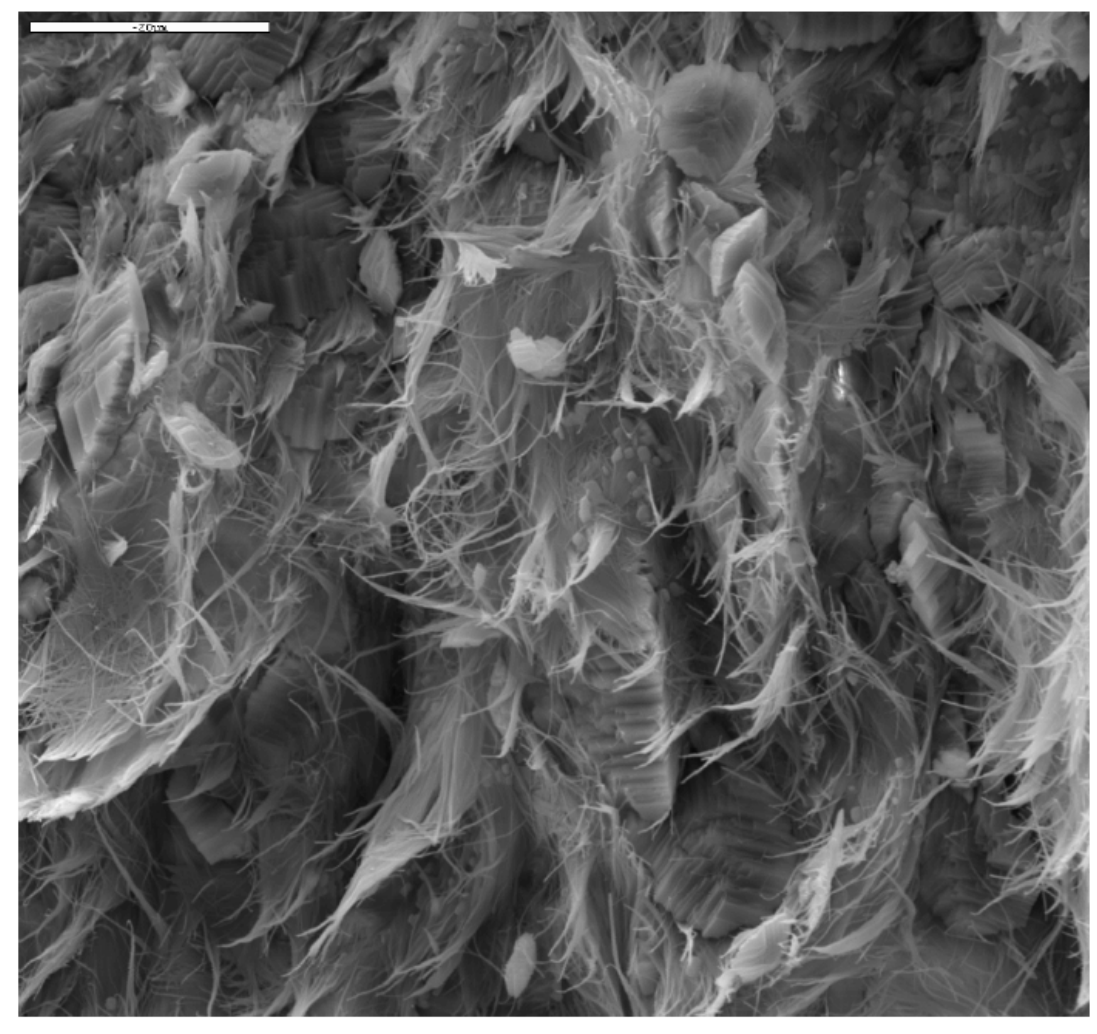

Fig. 14

Sample 1B -

Gold coated

broken surface

SEM image of

a palygorskite

rich part of

sample. The

image reveals

rhomb shaped

dolomite

crystals

interwoven and

potentially

cemented by

mats of fibrous

palygorskite.

The scale bar

top-left corner

is $20 \mu \mathrm{m}$ in

length.

Image courtesy

GMRS

Three samples representative of the Barzaman Formation were tested for XRD mineralogy yielding the following results:

1. Sample $2 \mathbf{A}$ - taken at a depth of approximately $49.8 \mathrm{~m}$, this sample comprised a weak mottled greenish white calcisiltite with trace manganese oxide visible in hand specimen. The XRD results indicated the following mineral proportions: dolomite $=81 \%$; palygorskite $=16 \%$; quartz $=2 \%$; and kaolinite $=1 \%$.

2. Sample 2B - taken at a depth of approximately $50 \mathrm{~m}$, this sample comprised a weak mottled greenish white calcisiltite/breccia. The XRD results indicated the following mineral proportions: dolomite $=69 \%$; palygorskite $=26 \%$; quartz $=4 \%$; and kaolinite $=1 \%$.

3. Sample 2C - taken at a depth of approximately $39 \mathrm{~m}$, this sample comprised a vein of soft green-grey slay-silt within a strong mottled reddish white carbonate siltstone, with numerous brown "ghosts". The XRD results indicated the following mineral proportions of the vein: palygorskite $=45 \%$; calcite $=27 \%$; quartz $=23 \%$ and dolomite $=2 \%$.

In addition to the XRD tests, dilute hydrochloric acid reaction and whole rock plasticity ${ }^{9}$ was determined on samples $2 \mathrm{~A}$ and $2 \mathrm{~B}$. Sample $2 \mathrm{~A}$ yielded a negligible reaction to dilute hydrochloric acid (indicating the lack of calcite) and exhibited extremely high plasticity: $\mathrm{LL}=135 \%$, PL $=76 \%$, PI $=59 \%$. Sample 2B gave a negligible reaction to dilute hydrochloric acid exhibited high plasticity: $\mathrm{LL}=70 \%, \mathrm{PL}=45 \%$, PI $=25 \%$.

\footnotetext{
${ }^{9}$ The test was carried out by crushing the rock until sufficient fines $<425$ micron in size were available to carry out the test. The liquid limit was carried out using the 4-point cone method as specified in BS1377:1990.
} 


\section{Geotechnical index properties}

It is likely that for a stratum such as the Barzaman Formation, formed over millions of years through many cycles of deposition and pedogenesis and in varying environmental conditions, considerable heterogeneity in the geotechnical characteristics of the deposit should be expected, both at specimen and at rock mass scale. For instance:

- the particle size distributions of the coarser size fraction would be expected to decrease with distance from the source of the sediments in the Oman Mountains;

- variations in the porosity and mineralogy of the dolomite-palygorskite \pm calcite matrix will result in differing mechanical behaviour, durability characteristics and geotechnical properties at specimen scale;

- the inhomogeneous distribution of palygorskite may result in significant variability in index test properties and strength and stiffness properties as well as variable water contents associated with shrink-swell behaviour of the mineral;

- the presence of de-dolomitised (i.e. calcite rich) "hard-ground" layers will result in variations in strength, stiffness and "excavatability" in the mass;

- relict wadi channels will result in significant permeability anisotropy in the mass; and,

- the formation of breccia pedogenic horizons, micro-faults and palaeosol horizons will yield local scale variations in structural behaviour.

This section of the paper will briefly discuss some initial observations of the effects of mineralogy and microstructure on the specimen scale index properties. Further discussion on the rock mass scale properties may be found in Macklin and Gaba (2009).

Atterberg Limits determinations have been made on ground rock fines $<425 \mu \mathrm{m}$ in size carried out using British Standard BS1377 Parts 1 and 2. In general, tests have focused on the finer grained fraction of the rock - that is the white to mottled white-red-green "calcisiltite". These data suggest that, in a disaggregated form, the rock is of high to extremely high plasticity. Approximately $20 \%$ of the data yield liquid limits in excess of $120 \%$, although they mostly fall below the A-line. These results are likely to reflect the significant proportions of palygorskite indicated by the XRD analyses.

For instance, data obtained from breccias and carbonate siltstone lithologies which are rich in green marl have higher plasticity indices, in the very high to extremely high plasticity range, compared with the conglomerate lithologies with lower clay content. Comparisons between XRD percentages of palygorskite and Atterberg Limits data do not however yield any reliable correlation due to significant heterogeneity in the mineralogy of the rock.

Typical water content determinations vary widely, between 4 and 30\% typically. Intact uniaxial compression strength varies widely, typically between 0.5 to $10 \mathrm{MPa}$, but does show a general non-linearly increasing trend with decreasing water content. This variability is again attributed to heterogeneity of the rock mineralogy and composition at hand specimen scale. Additional factors such as drying or softening and swelling of palygorskite rich components is also suspected to have affected results during the drilling and sample preparation stages. 
Bulk and dry densities returned by commercial laboratories vary widely between 1.5 to $2.6 \mathrm{Mg} / \mathrm{m}^{3}$ and 1.2 to $2.4 \mathrm{Mg} / \mathrm{m}^{3}$ typically. Porosity varies between 9 and $65 \%$ typically. However the particle density used in these determinations depends on mineral composition. For instance if it is assumed that the carbonate siltstone matrix/calcisiltite typically contains $85 \%$ dolomite (particle density, $\mathrm{G}_{\mathrm{s}}$ of 2.85$)$ and $15 \%$ palygorskite $\left(\mathrm{G}_{\mathrm{s}}\right.$ of 2.2$)$ by volume, then an average particle density of approximately 2.75 would be expected, slightly higher than typical assumptions of 2.65 to 2.7 . This is confirmed by specific tests for particle density carried out for the authors, with many results returning values of over 2.8 indicating high proportions of dolomite.

Mercury Intrusion Porosimetry (MIP) tests on samples of the calcisiltite matrix taken from Site 1 (sample 1B at 55m depth) were carried out at a commercial laboratory according to the authors' specification in order to investigate the nature of the matrix porosity. The MIP tests measured the amount of mercury intruded into the pore spaces of two small cubes of rock (5.4 and 11.3 grams dry weight) under vacuum. The amount of mercury intruded is proportional to the pressure applied and the diameter of the pores and this is calculated from the known surface tension and purity characteristics of the mercury. Thus, as the pressure is increased, smaller and smaller pores are filled with mercury.

The estimated particle density from the MIP tests for both samples was approximately $2.74 \mathrm{Mg} / \mathrm{m}^{3}$. The total porosity was determined as between 16 to $18 \%$ with a minimum pore diameter of $0.002 \mu \mathrm{m}$ and a maximum pore size of $55 \mu \mathrm{m}$ approximately. These results are summarised for each sample in Figure 15. From the figure it can be seen that $50 \%$ of pores are greater than 0.03 to $0.04 \mu \mathrm{m}$ in size.

Patsoules and Cripps (1989) presented similar data for another fine grained carbonate rock - chalk. Their data showed that the median pore size was approximately $0.4 \mu \mathrm{m}$ and yielded permeability values of 0.02 to 0.06 milliDarcy's - equivalent to 2 to $6 \mathrm{E}-10 \mathrm{~m} / \mathrm{sec}$ approximately ${ }^{10}$. Bell et al (1989) also quotes permeability data of around $1 \mathrm{E}-09 \mathrm{~m} / \mathrm{sec}$ for various English chalks with a mean porosity in the range 24 to $35 \%$. They considered that despite the apparently high porosities, the intrinsic permeability was very low on account of pore diameters in the range 0.39 to $0.65 \mu \mathrm{m}$, leading to water tension effects restricting water flow through the narrow pore throats.

Thus, for a median pore size approximately one tenth that of the chalk, and overall porosity up to one half typical values for chalk, very low intrinsic permeability should be expected for the calcisiltite matrix.

Dimension stone literature also suggests that rocks dominated by pore sizes in the range of $0.004-0.05 \mu \mathrm{m}$ are susceptible to honeycomb weathering. This occurs when salts crystallising from larger to smaller pores exert high expansion pressures on the rock fabric resulting in pitting and progressive breakdown of the rock. The MIP data discussed above suggests that up to $40 \%$ of the pore spaces lie within this size range and so the calcisiltite matrix may also be susceptible to slaking when exposed to saline water.

\footnotetext{
${ }^{10}$ The Darcy is a unit of measure of the intrinsic permeability of a porous medium. 1 Darcy is approximately equal to $1 \mathrm{E}-05 \mathrm{~m} / \mathrm{sec}$ permeability (hydraulic conductivity) under standard conditions. However variations in the temperature and salinity of the groundwater from the standard will modify the viscosity and density of the water, hence actual permeability (Fetter, 1994).
} 
Preliminary jar slake testing (after Czerewko \& Cripps, 1997) by the authors to assess the durability of samples of the Barzaman Formation also suggests that a significant proportion of the rock may be susceptible to a moderate or greater "risk of deterioration". Similar results have also been observed in 2cycle slake durability tests. This is considered to be related to volume changes and desiccation cracking due to drying, followed by swelling/softening of the palygorskite clays when wetted in the tests.

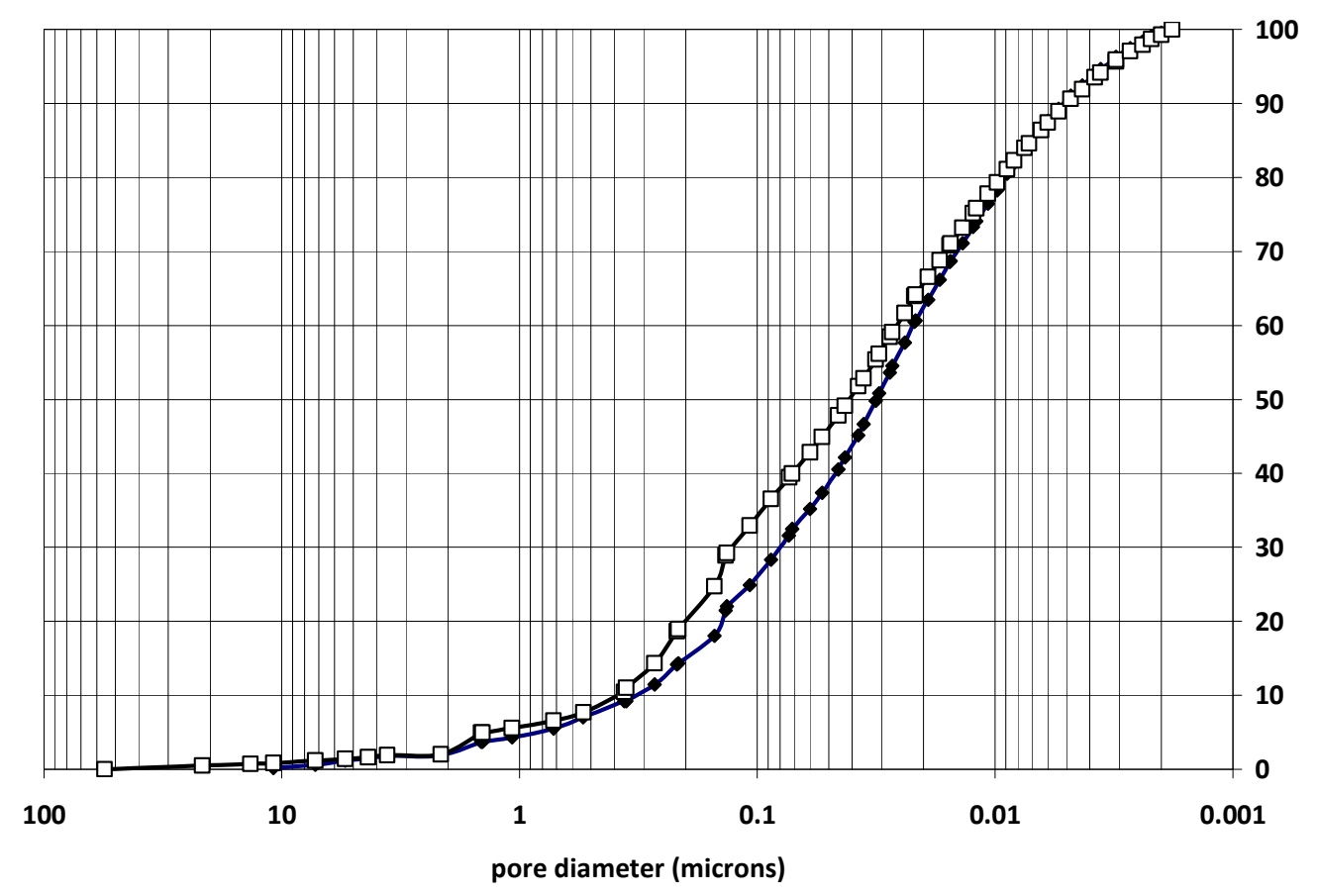

Fig. 15 Porosity size distribution for the white calcisiltite matrix; $50 \%$ of pores are greater than 0.03 to 0.04 micron in size

\section{Classification of the Barzaman Formation}

For the purpose of concise engineering field description and core logging the authors have considered three approaches to description and classification of the rocks of the Barzaman Formation - the simple dilute hydrochloric acid test $(10 \% \mathrm{HCl})$ already described above, the Clarke \& Walker descriptive scheme and a simple lithological classification scheme.

The terminology employed in the Clarke \& Walker scheme ${ }^{11}$ is well established in geotechnical investigations in Dubai, and is based on the strength of the rock, the proportions of non-carbonate to carbonate constituents and the grain size. For the most part, the rocks typically encountered in coastal Dubai fall within Clarke \& Walker's "slightly indurated - hard to moderately weak" strength range (UCS $=0.5$ to $12.5 \mathrm{MPa}^{12}$ ).

For those lithologies where the carbonate content is high, the terms "carbonate claystone" to "carbonate conglomerate (or breccia)" are permitted as

\footnotetext{
${ }^{11}$ Based largely on Folk (1959) and Fookes \& Higginbotton (1975).

${ }^{12}$ Equivalent to the Moderately Weak classification of BS5930:1999 (pre-Amd 1).
} 
alternatives to "calcilutite to calcirudite". Where the carbonate content is low, the terms "calcareous claystone" to "calcareous conglomerate" are employed.

However in applying this descriptive scheme the authors have found it potentially confusing on two counts:

1. The use of the term "claystone" for a high carbonate content rock does not follow the classification of mixed argillaceous clay-carbonate rocks ("marls") employed by Fookes \& Higginbottom (1975 - reproduced in Table 3).

\begin{tabular}{l|l}
\hline \% clay & terminology \\
\hline $0-5$ & Pure limestone \\
$5-20$ & Marly limestone \\
$20-35$ & Limey marlstone \\
$35-65$ & Marlstone \\
$65-80$ & Clayey marlstone \\
$80-95$ & Marly claystone \\
$95-100$ & Pure claystone \\
\hline
\end{tabular}

Table 3 - Fookes \& Higginbottom's compositional classification

In the authors opinion, the original Fookes \& Higginbottom approach is logical and the term claystone is preferred in the context of a clay rich (carbonate poor) rock type. Based on our estimates of clay (phyllosilicate) content in the rock from XRD mineralogy tests, we propose that the "claystone" alternative to calcilutite etc... should not be used.

2. The term "calcareous" is used for low carbonate content rocks in agreement with the terminology proposed by Fookes \& Higginbottom. However this term implies that the rock is rich in calcium carbonate. As discussed above, a typical reaction to the application of dilute $\mathrm{HCl}$ on core suggests that the majority of the rock matrix is dolomitic in composition. Whilst the presence of calcium carbonate rich horizons can be found ${ }^{13}$, our mineralogical tests also suggest that the majority of the white carbonate rock making up the calcisiltite clasts and/or matrix is predominantly dolomitic. As such we propose that the term "carbonate" would be more appropriate in place of "calcareous" when the proportion of dolomite to calcite is unknown.

Clarke \& Walker do permit the substitution of dolomite in the nomenclature however it is the author's experience that this is rarely done in routine geotechnical description in Dubai and so a simpler approach is considered appropriate.

\footnotetext{
${ }^{13}$ These zones are often associated with localised hard ground layers near present-day or historical phreatic zones, which is colloquially known as "Dubai Concrete".
} 
Table 4 Proposed modifications to Clarke \& Walker (1977) classification scheme, for the Barzaman Formation.

\begin{tabular}{|c|c|c|c|c|c|}
\hline Grain Size & $<0.002 \mathrm{~mm}$ & $\begin{array}{l}0.002 \text { to } \\
0.06 \mathrm{~mm}\end{array}$ & 0.06 to $2 \mathrm{~mm}$ & 2 to $60 \mathrm{~mm}$ & $\begin{array}{l}\text { Carbonate } \\
\text { content }\end{array}$ \\
\hline \multirow{4}{*}{$\begin{array}{l}\text { Strength: } \\
\text { "slightly } \\
\text { indurated" } \\
\text { Very Weak } \\
\text { to } \\
\text { Moderately } \\
\text { weak: } \\
<1.25 \text { to } \\
12.5 \mathrm{MPa} \\
\text { UCS } \\
\text { (BS5930: } \\
\text { 1999, pre- } \\
\text { Amd 1) }\end{array}$} & CALCILUTITE & CALCISILTITE & CALCARENITE & $\begin{array}{l}\text { (Notes } 1 \text { to } 3 \text { ) } \\
\text { CALCIRUDITE } \\
\text { or } \\
\text { Carbonate } \\
\text { BRECCIA } \\
\text { or } \\
\text { Carbonate } \\
\text { CONGLOMERATE }\end{array}$ & $>90 \%$ \\
\hline & $\begin{array}{l}\text { Clayey } \\
\text { CALCILUTITE }\end{array}$ & $\begin{array}{l}\text { Siliceous } \\
\text { CALCISILTITE }\end{array}$ & $\begin{array}{l}\text { Siliceous } \\
\text { CALCARENITE }\end{array}$ & $\begin{array}{l}\text { Conglomeratic } \\
\text { CALCIRUDITE } \\
\text { or } \\
\text { carbonate } \\
\text { BRECCIA or } \\
\text { (Note 5) } \\
\text { Carbonate } \\
\text { CONGLOMERATE }\end{array}$ & 50 to $90 \%$ \\
\hline & $\begin{array}{l}\text { (Note 4) } \\
\text { Carbonate } \\
\text { CLAYSTONE }\end{array}$ & $\begin{array}{l}\text { (Note 4) } \\
\text { Carbonate } \\
\text { SILTSTONE }\end{array}$ & $\begin{array}{l}\text { (Note 4) } \\
\text { Carbonate } \\
\text { SANDSTONE }\end{array}$ & $\begin{array}{l}\text { Carbonate } \\
\text { BRECCIA or } \\
\text { (Note 5) } \\
\text { Carbonate } \\
\text { CONGLOMERATE }\end{array}$ & 10 to $50 \%$ \\
\hline & CLAYSTONE & SILTSTONE & SANDSTONE & $\begin{array}{l}\text { CONGLOMERATE } \\
\text { or BRECCIA }\end{array}$ & 0 to $10 \%$ \\
\hline
\end{tabular}

Notes:

3. If clasts are SHELL, CORAL, ALGAL LUMPS OR PISOLITES use "calcirudite"

4. If clasts are ANGULAR fragments, use "breccia".

5. If clasts are ROUNDED fine gravel to cobble size, use "conglomerate".

6. The Barzaman Formation is dominated by dolomite - thus the use of the term "calcareous" gives a misleading impression that calcite is the dominant carbonate. Recommend using the $10 \% \mathrm{HCl}$ test and assigning mineralogical descriptor (Table 2 as appropriate - e.g. a "dolomitic calcisiltite" will have a weak reaction).

7. The "Carbonate CONGLOMERATE or BRECCIA" terms appears over carbonate content range 10 to $>90 \%$ so logs should describe rock type, angularity of clasts, the relative proportions of carbonate to foreign clasts, and relative proportion of fine grained matrix to clasts. 
An example of our proposed modification of the Clarke \& Walker scheme is shown (for the "slightly indurated" class or rocks) in Table 4. The strength range for very weak to moderately weak based on BS5930:1999 (pre Amd 1) has been used in place of the earlier version presented in Clarke \& Walker.

Additional notes to clarify the assessment of grain size have also been added, specific to the Barzaman Formation.

In recognition of the importance of the non-calcite carbonate mineralogy in this formation we suggest in Table 4 that the term "carbonate claystone or carbonate siltstone" be reserved for the transition lithologies between "clayey calcilutite and claystone" and "siliceous calcisiltite and siltstone", for example where the carbonate content (i.e. dolomite or calcite) lies between 10 and 50\%. That is, the term "calcareous" be replaced by "carbonate" to avoid any implication that calcite is the dominate carbonate mineral.

We do nonetheless, acknowledge that the prefix "calci-" may also be construed as implying a calcite dominant mineralogy. However we have retained this usage as alternatives can be clumsy and may not add significant clarification.

In addition we consider that the brecciated fabric is significant for the geotechnical characterisation and behaviour of this formation. However the Clarke \& Walker scheme limits the use of the "breccia" term to lithologies with $<10 \%$ or $>90 \%$ carbonate content. We have used the term for rock which has $>10 \%$ carbonate, with clearly angular and sub-angular fragments having a degree of fit between fragments indicating in situ brecciation and a lack of transport. We limit conglomerate to rock where it is clear the clasts have been transported (i.e. more rounded), and are different in composition from adjacent clasts and matrix.

In applying the Clarke \& Walker scheme we have found that whilst those authors do recommend that the relative proportions of clasts to matrix are routinely recorded, the classification makes no distinction between the carbonate and non-carbonate components - we consider that this should be recorded for the highly heterogeneous Barzaman Formation. For instance, in both drill core and open exposures we have noted that there is a frequently repeated lithological pattern comprising: brown conglomerate overlain by white conglomerate grading into "calcisiltite", in turn by breccia. Whilst this "apparent sequence" does vary between boreholes on an individual basis, excavation exposures typically reveal a recognisable continuity in this pattern on a large scale and thus indicates that cyclic environmental changes were operating during the deposition and alteration of these rocks.

We infer that the brown conglomerate is representative of the original fluvial ("wadi") conglomerate - largely unaltered by subsequent alteration. The other lithologies reflect the variations in the degree of alteration by the cementation processes. The clay rich breccia layers are inferred to represent a relict near surface horizon developed under fluctuating seasonal conditions. It is thus important that routine logging clearly distinguishes the key lithological differences in order to understand the underlying geological model.

One approach would be to use a tripartite classification based upon the relative proportions of the three main components of the rock as visible in hand specimen. This is similar to that adopted by Fookes (1988) and Ouhadi \& Yong (2003) for carbonate-clay-quartz bearing rocks. The classification is thus based on the proportions of the following constituents: 
1. The fine grained dolomitic calcisiltite/calcilutite, which occurs either as a distinct lithology, as fragments within the breccia or conglomerate or as the matrix to the conglomerate;

2. The highly plastic dolomite-palygorskite "silt" that occurs as discrete veins cross cutting bedding, as discrete inclusions within the calcisiltite, or as part of the matrix within the white and brown conglomerate; and,

3. The clasts (typically cobble to sand sized particles) that make up the coarse component of the conglomerates - these comprise partially altered gabbro, red and green chert, highly weathered brown harzburgite and some limestone depending on source area.

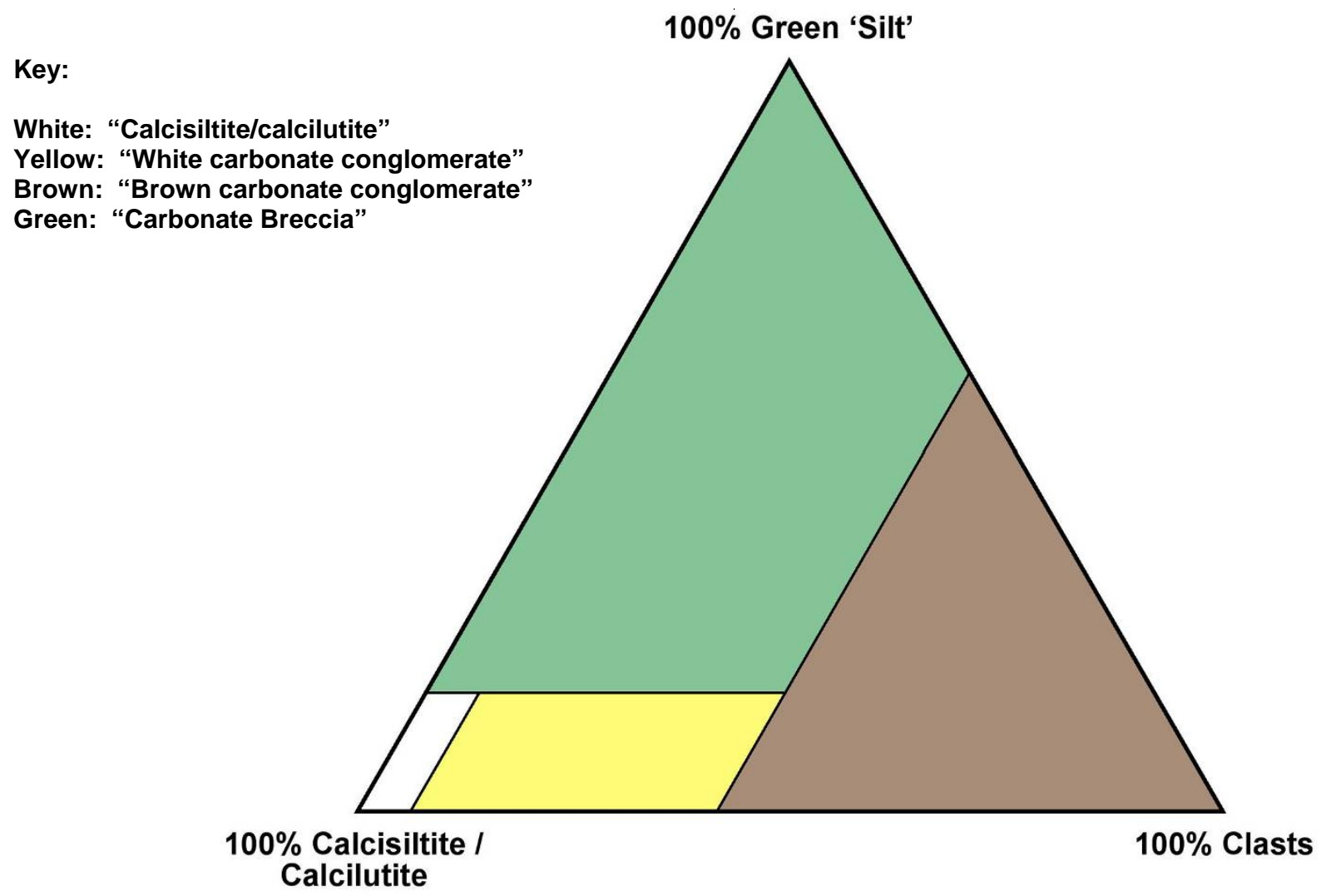

Fig. 16 Suggested ternary diagram classification for the Barzaman Formation.

The relative proportions of each of these three key constituents of the rock can thus be plotted on a ternary diagram (Figure 16). The apices of the diagram represent $100 \%$ of each component and the proportions of two of these components automatically define the third. By considering lengths of core of like constituent proportions, it would then be possible to classify the Barzaman Formation in a consistent manner, to reflect the discrete layers that are visible in open excavations.

Using the ternary diagram classification typical proportions of the four main lithologies can thus be determined within a borehole. For example, Table 5 summarises the results of our review of nearly fifty boreholes across the coastal area of Dubai. 


\begin{tabular}{l|cc}
\hline Lithology & $\begin{array}{c}\text { Mean } \\
\text { proportions }\end{array}$ & Typical range \\
\hline Carbonate breccia & $3 \%$ & $\pm 2 \%$ \\
Calcisiltite & $50 \%$ & $\pm 30 \%$ \\
"white" Carbonate & $35 \%$ & $\pm 20 \%$ \\
$\begin{array}{l}\text { conglomerate } \\
\text { "brown" }\end{array}$ & $12 \%$ & $\pm 10 \%$ \\
Conglomerate & $100 \%$ & \\
\hline \multicolumn{1}{r}{ total } & & \\
\hline
\end{tabular}

Table 5 Estimate of typical proportions of the four key lithologies encountered in vertical cored boreholes, coastal Dubai

\section{Conclusions}

This paper has reviewed published data on the cemented and altered conglomerate deposits of possible Mio-Pliocene age exposed around the foothills of the Oman Mountains termed the Barzaman Formation. By examination of these natural outcrop, road cuttings, quarry exposures, it is proposed that the term Barzaman Formation should also be applied to the "conglomeratic siltstone" frequently encountered in temporary excavations and borehole cores in coastal Dubai up to $60 \mathrm{~km}$ to the west.

Temporary excavations have provided an opportunity to study the distribution of the various lithologies and to develop a ground model for this formation. This work has indicated that the Barzaman Formation is essentially a series of terrestrial alluvial plain deposits, modified by subsequent diagenetic alteration (cementation) and "pedogenic" (i.e. soil and duricrust forming) processes over repeated climatic cycles throughout the Mio-Pliocene. Open excavations reveal that these deposits are shallow dipping, locally with preserved channels. Groundwater flows are also commonly concentrated within the channel features, reflecting higher permeability (and less secondary dolomite-palygorskite cement) than the calcisiltite/calcilutite dominant lithologies.

It is thus suggested that the Barzaman Formation was formed by the following processes:

1. During the late Miocene - Pliocene uplift and erosion of the Oman Mountains provided a source of coarse grained ophiolitic sediments, deposited within channels and outwash plains during humid climatic conditions;

2. Extended periods of arid conditions resulted in high evaporation rates and mobilisation of dissolved carbonates. Precipitation of these carbonates resulted in cementation and modification of the original deposits, forming the dolomite rich white conglomerate;

3. "Auto-brecciation" near the ground surface occurred associated with nearsurface seasonal volume changes during non-erosive phases, or due to channel migration; 
4. With increasing rainfall, further wadi and outwash plain deposits brought new coarse grained material into the deposit, re-commencing the process described above; and,

5. Pervasive alteration of harzburgite and other clasts and authigenic growth of dolomite cements as well as palygorskite clay (derived from weathering of the magnesium rich sediments) by hyper-alkaline ground waters since the Miocene.

For concise routine engineering descriptions of this formation, a simple ternary classification scheme has also been proposed based on visual estimates of the proportions of the green marl (actually a mix of palygorskite and dolomite); the calcisiltite/calcilutite component; and clasts making up the sand to cobble sized component of the rock.

Due to the dominance of dolomite and palygorskite clay in the fine grained "calcisiltite", slight modifications are proposed to the Clarke \& Walker (1977) descriptive classification logging scheme routinely used in Dubai. It is also recommended that the Clarke \& Walker scheme should be routinely complimented with dilute hydrochloric acid tests on hand specimen/cores in order to assess whether dolomite or calcite are the dominant carbonate mineralogy.

Mineralogical studies indicate that dolomite and palygorskite (of the sepiolite group of clays) dominate the mineralogy of the mottled "calcisiltite" which forms the matrix cement for most of this formation. On account of the particular characteristics of palygorskite, a number of geotechnical issues in terms of determining reliable index properties have briefly been identified.

Acknowledgements The authors would like to thank Mike Eden of GMRS laboratories for petrographic and micro-structural analysis; Dr Sarah Arkley and Dr Esad Porovic for assistance in the field in Dubai and Yung Loo for his enthusiasm and attention to detail in the background studies. Thanks also to Ove Arup \& Ptns for permitting access to drill cores and research funding to carry out laboratory testing.

\section{References}

Abrams MJ and Chadwick OH (1994). Tectonic and climatic implications of alluvial fan sequences along the Batinah coast, Oman. J of the Geol. Soc. Vol. 151, $51-58$.

Aiban, S. A. (2006) Compressibility and swelling characteristics of Al-Khobar Palygorskite, eastern Saudi Arabia. Engineering Geology, 87, 205-219.

Aiban, S. A. (2007) Reply to the Discussion by Shahid Azam on "Aiban, S. A. (2006)

Compressibility and swelling characteristics of Al-Khobar Palygorskite, eastern Saudi Arabia, Engineering Geology 87(3-4):205-219”. Engineering Geology, 92, 173-180.

Alrifai L (2007). Rock socket piles at Mall of the Emirates, Dubai. Proc. Institution of Civil Engineers, GE160, April 2007, Issue GE2, pp. 105 - 120.

Alsharhan AS and Kendall CGstC (2003). Holocene coastal carbonates and evaporites of the southern Arabian Gulf and their ancient analogues. Earth Science Reviews. Vol. 61, pp $191-$ 243.

Anthony JW, Bideaux RA, Bladh KW and Nichols MC (2001). Handbook of Mineralogy. Mineralogical Society of America. Mineral Data Publishing.

Aqrawi, A. A. M. (1993) Palygorskite in the recent fluvio-lacustrine and deltaic sediments of Southern Mesopotamia. Clay Minerals, 28, 153-159.

Baker WF et al (2007). Burj Dubai: Engineering the world's tallest building. In: The structural design of tall and special buildings. Vol. 16, 361 - 375. Wiley Interscience.

Boote, DRD, Mou, D and Waite, RI (1990). Structural evolution of the Suneinah Foreland, Central Oman Mountains. 397-418 in The Geology and Tectonics of the Oman Region. Robertson, A H F, Searle, M P and Ries, A C (editors). Geological Society, London, Special Publication 49. 
Brindley GW \& Brown G (1980). Crystal structures of clay minerals and their X-ray identification. Mineralogical Society.

British Standards Institution (1999). BS5930: 1999 Code of Practice for Site Investigations. British Standards Institution (1999). BS5930: 1999 Incorporating Amendment 1 (2007). Code of Practice for Site Investigations.

Brook, M. 2006. Water Resources of Abu Dhabi Emirate. Water Resources Dept, Environment Agency, Abu Dhabi.

Burnett, A. D. \& Epps, R. J. (1979). The engineering geological. description of carbonate suite rocks and soils. Ground Engng,. March, 41-48.

Cagatay, N. M. (1990) Palygorskite in the Eocene Rocks of the Dammam Dome, Saudi Arabia. Clays and Clay Minerals, 38, 299-307.

Callen, R. A. (1981) Clays of the Palygorskite-Sepiolite group: Depositional environment, age and distribution. Developments in Sedimentology, 37, 1-37.

Ciullo PA (1996). Industrial Minerals and Their Uses: A Handbook and Formulary, 1st ed. William Andrew Publishing.

Clarke AR and Walker BF (1977). Technical Note: A proposed scheme for the classification and nomenclature for use in the engineering description of Middle Eastern sedimentary rocks.

Geotechnique, Vol. 27 (1), pp. 93 - 99.

Cobanoglu I et al (2008). Microstructural, geochemical and geomechanical properties of caliche deposits from the Adana Basin, Turkey. Bull. Eng. Geol. Environ. Vol. 67, pp367 - 374.

Czerewko MA \& Cripps JC (1997) Assessing the durability of mudrocks using the modified jar slake durability test.

Czerewko MA \& Cripps JC (1997) Simple index tests for assessing the durability properties of mudrocks. The Geotechnics of Hard Soils - Soft Rocks, Evangelista \& Picarelli (eds.).

Edgell, H. S. (2006) Arabian Deserts: Nature, Origin and Evolution. Springer, Netherlands.

Farrant AR et al (2006). Geology of the Al Dhaid 1:100,000 map sheet, 100-2, United Arab

Emirates. (Keyworth, Nottingham: British Geological Survey). Ministry of Energy, United Arab

Emirates, 2006.

Fetter CW (1994). Applied hydrogeology. 3rd edition, Prentice Hall.

Folk RL (1959). Practical petrographic classification of limestone. Bull. Am. Assoc. Petroleum Geologists, Memoir. $62-85$.

Folk, RL (1959) Practical petrographic classification of limestones, AAPG Bulletin, Vol. 43, No.

1, pp. 1-38.

Fookes P G (1988). The geology of carbonate soils and rocks and their engineering

characterisation and description. Engineering for Calcareous Soils (Jewell and Khorshid, eds).

Balkema.

Fookes PG and Higginbottom IE (1975). The classification and description of near shore carbonate sediments for engineering purposes. Geotechnique, Vol. 25, $406-411$.

Galan, E. (1996) Properties and applications of Palygorskite-Sepiolite Clays. Clay Minerals, 31, 443-453.

Glennie KW (2005). The Deserts of South Eastern Arabia. Geoarabia, Gulf petrolink.

Government of United Arab Emirates (1979). Geological Map of the Emirates. Hunting Surveys

Government of United Arab Emirates (1979). Ministry of Petroleum and Mineral Resources.

Geological Map of the Emirates. 1:250,000 scale. Hunting Geology and Geophysics Ltd.

Isphording, W. C. (1973) Discussion of the occurrence and origin of sedimentary Palygorskite-

Sepiolite deposits. Clays and clay minerals, 21, 391-401.

Macklin S and Gaba A(2009). Engineering in the Barzaman Formation. Coastal Dubai, UAE.

Proc. ICE. Civil Engineering 162, November 2009, pp $18-24$.

Maizels JK (1988). Palaeochannels: Plio-Pleistocene raised channels systems of the western

Sharqiyah. Journal of Oman Studies, Special report No. 3, pp95 - 112.

Micheels A, Brucha A A, Dieter, U, Utescherd, T and Mosbrugge, V. 2007. A Late Miocene climate model simulation with ECHAM4/ML and its quantitative validation with terrestrial proxy data. Palaeogeography, Palaeoclimatology, Palaeoecology, Vol 253, 251-270.

Ogg, J.G., Ogg, G and Gradstein, F.M. (2008) "The Concise Geologic Time Scale”. International Commission on Stratigraphy.

Ouhadi, V. R. \& Yong, R. N. (2003). The role of clay fractions of marly soils in their post stabilization failure. Engineering Geology, 70, 365-375.

Paquet, H. \& Millot, G. (1972) Geochemical evolution of clay minerals in the weathered products in soils of Mediterranean climate. Proceedings of International Clay Conference, Madrid, 199-206. Pascucci V et al (2008). Seismic hazard and seismic design requirements for the Arabian Peninsula Region. Proc. $14^{\text {th }}$ World Conf. on Earthquake Engineering, October $12-17,2008$, Beijing, China. 
Rodriguez-Navarro, C.; Sebastian, E.; Doehne, E. \& Ginell, W. S. (1998) The role of SepiolitePalygorskite in the decay of ancient Egyptian limestone sculptures. Clays and clay minerals, 46(4), 414-422.

Singer, A. (1979). Palygorskite in Sediments: Detrital, Diagenetic or Neoformed - A Critical Review. Geologische Rundschau, 68(3), 996-1008.

Styles, M T, Ellison, R A, Arkley, S L B, Crowley, Q, Farrant, A R, Goodenough, K M, McKervey, J A, Pharaoh, T C, Phillips, E R, Schofield, D and Thomas, R J. 2006. The Geology and Geophysics of the United Arab Emirates. Volume 2: Geology. (Keyworth, Nottingham: British Geological Survey). 